\title{
Drill hole CS-1 penetrating the Cínovec/Zinnwald granite cupola (Czech Republic): an A-type granite with important hydrothermal mineralization
}

\author{
Miroslav ŠTEMPROK
}

Institute of Petrology and Structural Geology, Faculty of Science, Charles University, Albertov 6, 12843 Prague 2, Czech Republic; miroslav.stemprok@natur.cuni.cz

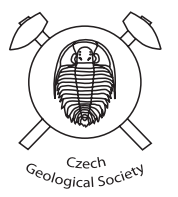

\begin{abstract}
The Sn-W deposit at Cínovec and Zinnwald (Eastern Krušné hory/Erzgebirge) is associated with a granite cupola of Late Variscan age intruded into the Teplice rhyolite. The 1596 m deep CS-1 drilling was completed in 1961-1963 at Cínovec in the center of the granite cupola. This paper reviews earlier and new petrological and geochemical data revealed by the CS-1 drill core. The drill-log showed that the upper granite zone of the cupola consists of lepidolite-albite granite grading continuously into zinnwaldite granite in fine-grained and medium-grained variants. Below 730 m depth, medium-grained, porphyritic lithian annite granite enclosing small bodies of porphyritic lithian annite microgranite was observed. Chemical analyses of the drill core are discussed in terms of increasing depth, significant textural variations and trace-element concentrations for As, Ba, Be, Bi, Mo, Nb, Rb, Sn, Th, U, Y, W, and $\mathrm{Zr}$. The zinnwaldite/lithian annite transition in the granite profile is well demonstrated by the abrupt changes in Li, Fe and Ti concentrations with depth. High concentrations of Sn, W, and Bi are mainly confined to the greisen zones, associated with both sub-horizontal and steep fissure systems. As a consequence of subsolidus albitization, the pink coloration of lithian annite granite was changed to white-grey in the upper cupola zone above $c .730 \mathrm{~m}$ depth. The textural changes are interpreted as modifications of earlier microgranites by the later emplacement of medium-grained granites along sharp contacts. The major effect of subsolidus hydrothermal alteration is manifested by pervasive development of lepidolite and zinnwaldite at the expense of earlier lithian annite and by an intense albitization (Ab $\sim 98$ mol. \%) reaching a depth of $c .730 \mathrm{~m}$ below the surface. The hydrothermal overprinting in the CS-1 drill core is interpreted to be caused by fluids derived from a deep lower crustal source, probably near the boundary with the mantle, as witnessed by the coexistence of lamprophyres and albite-rich granites in several ore districts of the Krušné hory/Erzgebirge with Li, Sn, and W mineralization.
\end{abstract}

Keywords: Cínovec/Zinnwald, A-type granite, zinnwaldite, lithian annite, rare-metal mineralization

Received: 5 June, 2016; accepted: 10 January, 2017; handling editor: V. Rapprich

The online version of this article (doi: 10.3190/jgeosci.226) contains supplementary electronic material.

\section{Introduction}

Rare-metal deposits (Sn, W, Mo, Ta and Nb) are spatially associated with felsic magmatism (Pirajno 2009 and references therein). Indeed, the original definition of S-type granites by Chappell and White (1974) suggests their association with tin mineralization. In-situ fractional crystallization of granitic melts has been advocated as a predominant explanation of rare-metal concentration in residual silicate melts and their evolving hydrothermal fluids (Groves and McCarthy 1978; Lehman 1982; Černý et al. 2005; Chappell and Hine 2006). Other mechanisms for rare-metal concentration invoked primary enrichment of a crustal source (Pollard et al. 1988; Romer and Kroner 2015) and concentration of some large-ion lithophile (LIL) elements in fluids/melts liberated from the lower crust in course of the granulite-facies metamorphism (Cuney and Barbey 2014). More recently has been proposed the effect of pulses from the mantle interacting with the lower crust to form granitic magmatism and providing the addition of rare metals derived from the mantle (Štemprok and Seifert 2011).

According to the fractional crystallization hypothesis, compatible elements are progressively removed from a melt. Consequently smaller volumes of differentiated melt become enriched in incompatible components and volatiles, including water, which eventually exsolve. The dyke equivalents of albite-rich granitic rocks known locally as "ongonite" in Mongolia (Kovalenko et al. 1970), appeared at that time to support this hypothesis.

Fractional crystallization hypothesis differs from the metasomatic model of the origin of rare-metal granites developed by Jacobson et al. (1958) in anorogenic granites of Northern Nigeria and by Beus et al. (1962) in post-collisional settings on the territory of the former USSR. This mechanism accounts for the metasomatic overprinting of the endocontacts of mineralized granites 
by external hydrothermal solutions to explain their enrichment in LILE and some rare metals.

In the present review, results from drill core CS-1 (Cínovec/Zinnwald) are being re-examined and the concept of a primary sodium-rich felsic melt called into question. Previous data are included, especially on (1) contacts between individual textural variants of granites, (2) major- and trace-element compositions, and (3) changes of Li-Fe mica compositions

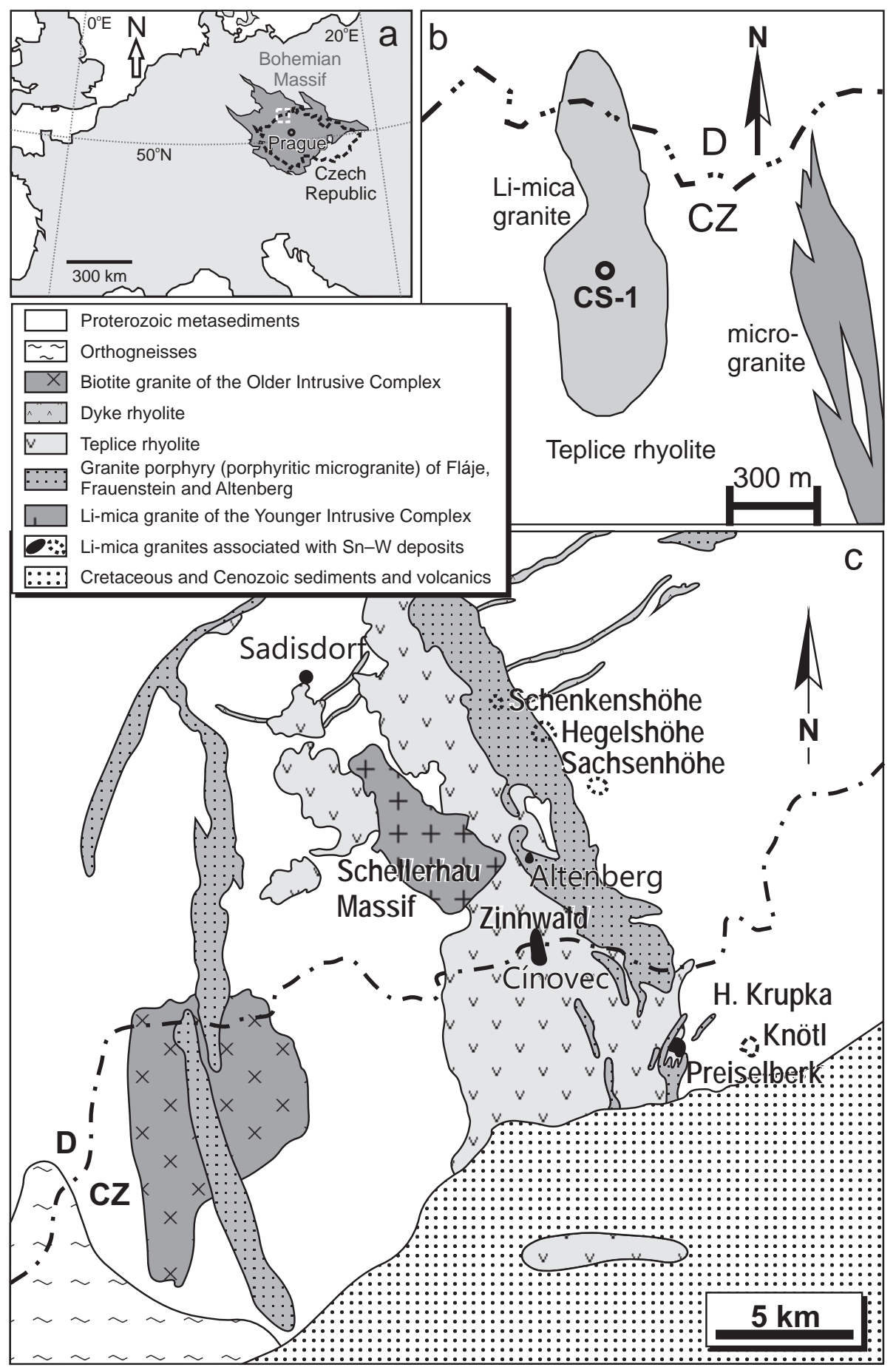

with depth. However, they are subject to detailed reexamination in the light of current hypotheses including the results of the recent study on ongonites from Mongolia (Dostal et al. 2015).

\section{Geological setting of the Cínovec/ Zinnwald granite cupola}

\subsection{Geological position in the Bohemian Massif}

The studied Cínovec/Zinnwald cupola is located in the NW part of the Bohemian Massif in the Eastern Krušné hory/Erzgebirge. The crystalline basement includes Proterozoic and Paleozoic lithologies intruded by a sequence of Variscan granites forming the Krušné hory/ Erzgebirge Batholith (KHEB). The Altenberg-Teplice caldera (ATC; Fig. 1) is a large elliptical collapse structure, 630 $\mathrm{km}^{2}$ across, which contains a succession of felsic volcanic rocks and subvolcanic biotite granite intrusions (Mlčoch and Skácelová 2010; Walther et al. this issue). Various granite intrusions are hidden and their apical parts are observed near the surface and in drill cores of numerous drillings. According to geophysical and geological evidence, large subsurface accumulations of granitic rocks were emplaced in a NW-SE trending belt with the Cínovec granite cupola as the highest elevation of the hidden relief of the Cínovec/Krupka Pluton (Štemprok et al. 1994).

Fig. 1a - Geological position of the eastern Krušné hory/Erzgebirge area in the Bohemian Massif (white quadrangle); $\mathbf{b}$ - Geological map of the outcrop of Cínovec/Zinnwald granite cupola with the position of the drill hole CS-1; c - Geological map of the eastern Krušné hory/Erzgebirge from Dolejš and Štemprok (2001). 


\subsection{Petrography and modal composition of the granite cupola}

The Li-Fe granites of the Cínovec/Zinnwald cupola form an outcrop of $1.4 \times 0.3 \mathrm{~km}$ size covered by c. $10 \mathrm{~m}$ thick granite residuum and rock fragments. The drilling CS-1 was completed in the center of the granite outcrop in 1961-1963 (Fig. 1). The drill core has been the target of numerous studies in course of more than fifty years. The petrology, density, porosity and geochemistry of the granites were studied by Štemprok (1965), Chlupáčová and Štemprok (1965), Štemprok and Šulcek (1969). Additional mineralogical and geochemical data were presented in Rub et al. (1983, 1997, 1998), Cocherie et al. (1991), and Dolejš and Štemprok (2001). The compositions of rock-forming minerals including some accessory minerals were determined by electron microprobe analyses by Johan and Johan (2005), Johan et al. (2012) and Breiter and Škoda (2012). The results of the new sampling and new interpretation of chemical analyses were presented at workshop held in Prague in 2015 (Breiter et al. 2015a, b; Rambousek and Knésl 2015).

The drilling CS-1 made it possible to distinguish in the vertical profile the upper and lower granite suites essentially on the basis of dark mica composition and rock color (Štemprok 1965; Rub et al. 1983, 1998). Figure 2 shows granite textural variants in the core profile and the changes of modal composition with depth. The amount of orthoclase varies between 20 and 40 vol. \%. Plagioclase represented exclusively by albite is unzoned, its amount is significantly different in the upper granites (up to $\sim 35 \mathrm{vol}$. $\%)$ whereas in the lower suite it is $20-25$ vol. \%. The amount of quartz greatly varies from 20

Fig. 2 Geological profile of the bore hole with the distribution of rockforming minerals (based on planimetric analyses in Štemprok 1965, values at $1527.3 \mathrm{~m}$ depth averaged). Notation: fgLG - fine-grained lepidolite granites and greisens, mgZG - medium-grained zinnwaldite granite, $\mathrm{mg} / \mathrm{pZG}$ - alternation of medium-grained zinnwaldite granite and porphyritic microgranite, pZG - porphyritic zinnwaldite microgranite, mg-pBG - porphyritic medium-grained lithian annite granites, $\mathrm{pBG}$ - porphyritic lithian annite microgranite, $\mathrm{f} / \mathrm{mgBG}$ - alternation of porphyritic lithian annite microgranite and porphyritic medium-grained lithian annite granite (Dolejš and Štemprok 2001). le - lepidolite, zw - zinnwaldite, lia - lithian annite. to $c .50$ vol. \% and varies on a dm scale due to uneven distribution of quartz phenocrysts or quartz grain clusters. The amount of trioctahedral mica changes usually from 4 to 6 vol. \%, with exceptions of the amounts below 1 vol. $\%$ in a zone between 300-350 $\mathrm{m}$. The sum of modal quartz and feldspars reaches $90-95$ vol. \%, while quartz/ feldspars ratio varies from 0.3 to $\sim 1.2$.

Figure 1 shows the outcrop of Li-Fe mica granites without distinction between lepidolite and zinnwaldite types. In the CS-1 drill core, the granitic rocks have been subdivided into the upper and lower suite granites (Rub et al. 1983). The upper suite consists of lepidolite or zinnwaldite-bearing granites in fine- (microgranitic) and medium-grained variants.

Fine-grained lepidolite-albite granite occurs in the apical part to a depth of $c .90 \mathrm{~m}$ and consists of albite (38-44 vol. \%), quartz (28-35\%), orthoclase (14-21\%), sericite $(5-10 \%)$ and of $\mathrm{Fe}$ lepidolite $(1.5-2 \%)$. It contains rare Ta-enriched columbite, $\mathrm{U}$ microlite and struverite (Rub et al. 1998). Some quartz crystals enclose albite inclusions exhibiting a characteristic "snow flake" textures described by Beus et al. (1962) from apogranites or Kovalenko et al. (1970) from ongonites.

These granites are underlain by medium-grained zinnwaldite granite with a seriate texture. Orthoclase (29-41 vol. \%) forms allotriomorphic singular or twinned grains up to $5 \mathrm{~mm}$ across. Albite (29-34 vol. \%) occurs in laths $(0.2$ to $1.5 \mathrm{~mm})$ and is concentrated mainly in

\section{volume \%}

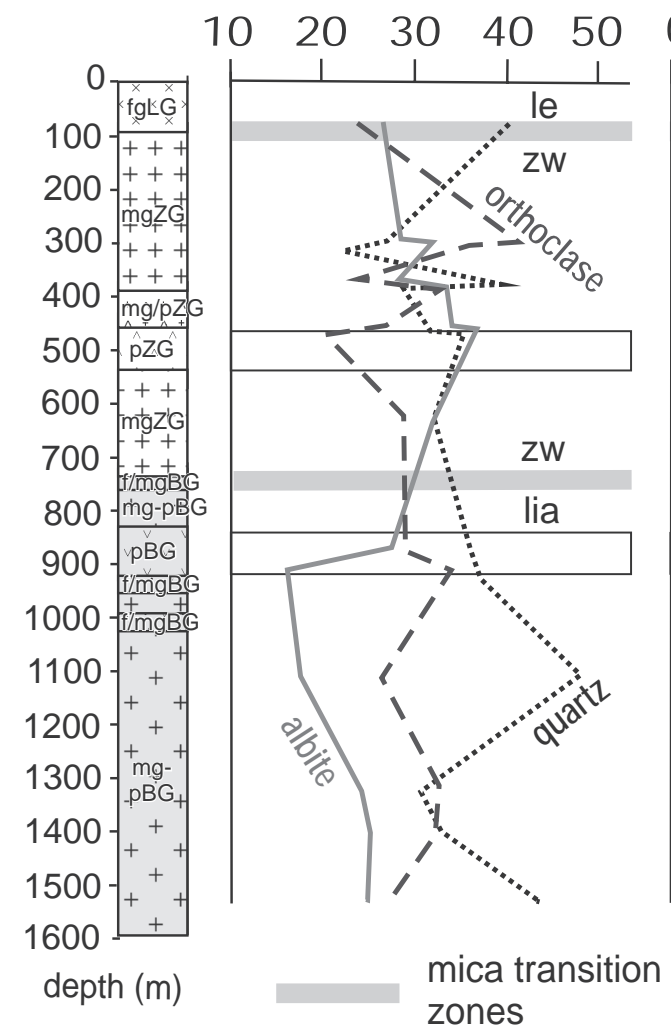

quartz/feldspars ratio

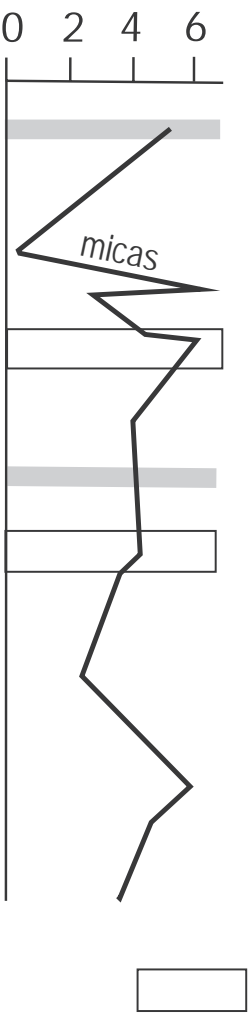

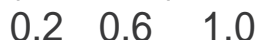

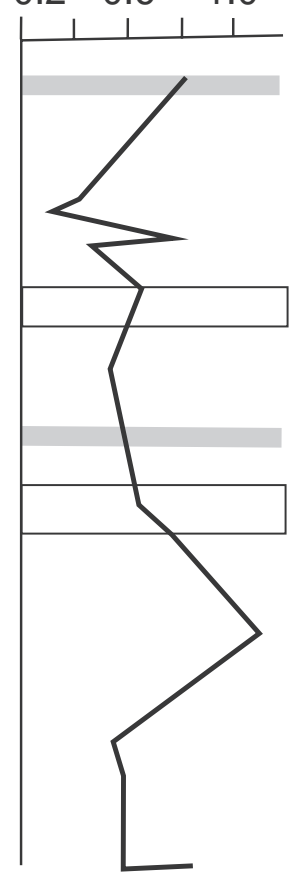

microgranites 


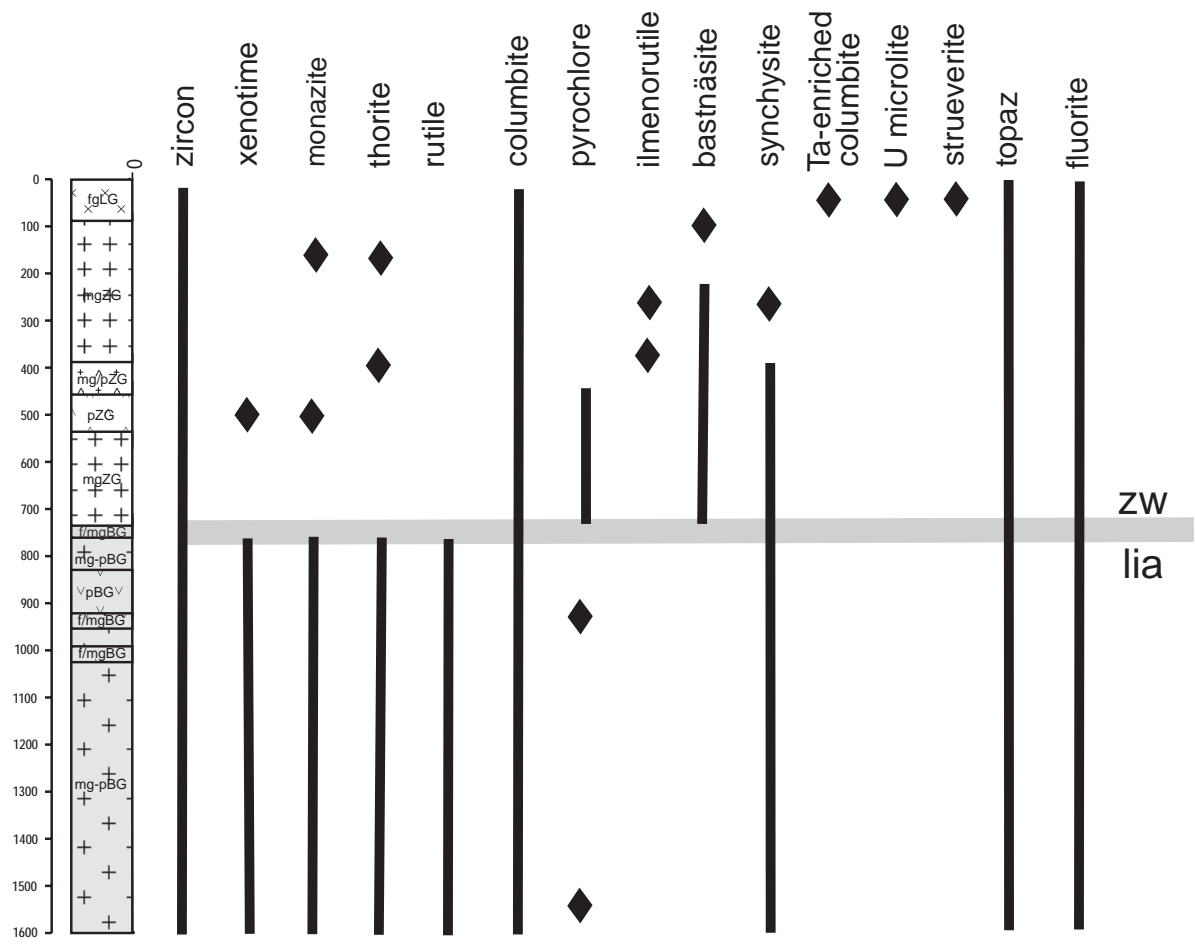

Fig. 3 Distribution of accessory minerals in the profile of CS-1. Simplified according to the data by Cocherie et al. (1991), Rub et al. (1998), and Johan and Johan (2005). interstices of quartz and orthoclase grains $(3-5 \mathrm{~mm})$, where it may form monomineral aggregates. Accessory minerals include topaz, fluorite, Hf-rich zircon, monazite, xenotime, thorite, columbite, pyrochlore, ilmeno-rutile, bastnäsite, synchisite and fluorite (Cocherie et al. 1991; Rub et al. 1998; Breiter and Škoda 2012; Fig. 3). In the granites of the ore zone cassiterite occurs in hypidiomorphic grains, accompanied by less abundant wolframite, scheelite, pyrite and sphalerite. Secondary minerals include sericite, kaolinite (dickite), hematite and calcite.

The predominant variety in the upper suite is mediumgrained seriate zinnwaldite granite (Fig. 4a). Zinnwaldite microgranite is represented in the CS-1 drill core from $369 \mathrm{~m}$ downwards with several variants. They occur as 0.5 to $15 \mathrm{~m}$ thick interchanging with medium-grained zinnwaldite granite and as a continuous body from c. 450 to $530 \mathrm{~m}$ depth in the center of the cupola (Fig. 2). Such textural interplay of medium grained and fine-grained zones was repeated at a depth of 724-750 m. Contacts are usually sharp, but exceptionally they appear also gradational. Most of the contacts dip 30 to $45^{\circ}$ but some are steeply inclined $\left(70-80^{\circ}\right)$. Microgranite is a compact dark grey rock consisting of quartz (32-40 vol. \%), albite (29$37 \%$ ), orthoclase (20-27\%) and zinnwaldite (4-6\%: Fig. $4 \mathrm{~b}-\mathrm{c}$ ). Quartz phenocrysts are up to $7 \mathrm{~mm}$ across, globular, or stubby columnar often with overgrowths of a younger quartz generation. Perthitic orthoclase forms singular, twinned grains and aggregates up to $5 \mathrm{~mm}$ in size. It encloses randomly orientated albite laths, $0.2-0.5$ $\mathrm{mm}$ long. Secondary minerals are sericite, kaolinite, hematite and calcite. The lower section of the drill core consists of lithian annite granites marked with porphyritic phenocrysts of orthoclase and of globular quartz. They consist of quartz (32-39 vol. \%), albite (27-31 vol. \%), perthitic alkali feldspar (20-34 vol. \%) and lithian annite (formerly called protolithionite; c. 4 vol. \%) as the only mafic mineral. The abundance of accessory topaz and fluorite is lower compared with the granites in the upper suite but the amount of zircon is slightly increased.

Lithian annite porphyritic microgranite (Fig. 4d) forms a continuous body from 823.4 to $c .925 .0 \mathrm{~m}$ (Fig. 2) interrupted by a layer of medium-grained lithian annite granite at 915 to $922 \mathrm{~m}$. The microgranite consists of c. 23 vol. \% albite, $31 \%$ orthoclase, $38 \%$ quartz and $4 \%$ lithian annite. Down to the bottom of the known profile several such minor layers occur. Medium-grained lithian annite granite, occasionally porphyritic, forms a continuous body from $1020 \mathrm{~m}$ downward (Figs 2, 4e-f). The rock is grey or pinkish with phenocrysts of orthoclase up to $3 \mathrm{~cm}$ and globular quartz up to $2 \mathrm{~cm}$ or lithian annite flakes, isolated or in aggregates up to $0.5 \mathrm{~cm}$. In places the granite contains pegmatitic schlieren or pock-

Fig. 4 Textural types of the granites: a - white-grey, albite-rich medium-grained zinnwaldite granite with a seriate texture (depth $649.7 \mathrm{~m}$ ); b - dark grey, porphyritic zinnwaldite microgranite with K-feldspar and quartz phenocrysts (499.6 m); c - porphyritic zinnwaldite microgranite with a zone of hematitisation $(429.5 \mathrm{~m})$; d - lower suite porphyritic lithian annite microgranite with a veinlet of K-feldspar (837.5 m); e porphyritic medium-grained to fine-grained lithian annite granite with $\mathrm{K}$-feldspar and quartz phenocrysts $(1569.0 \mathrm{~m})$; $\mathbf{f}$ - pink medium-grained porphyritic lithian annite granite with globular quartz phenocrysts and pink K-feldspar in single grains and aggregates $(1506.5 \mathrm{~m})$. 


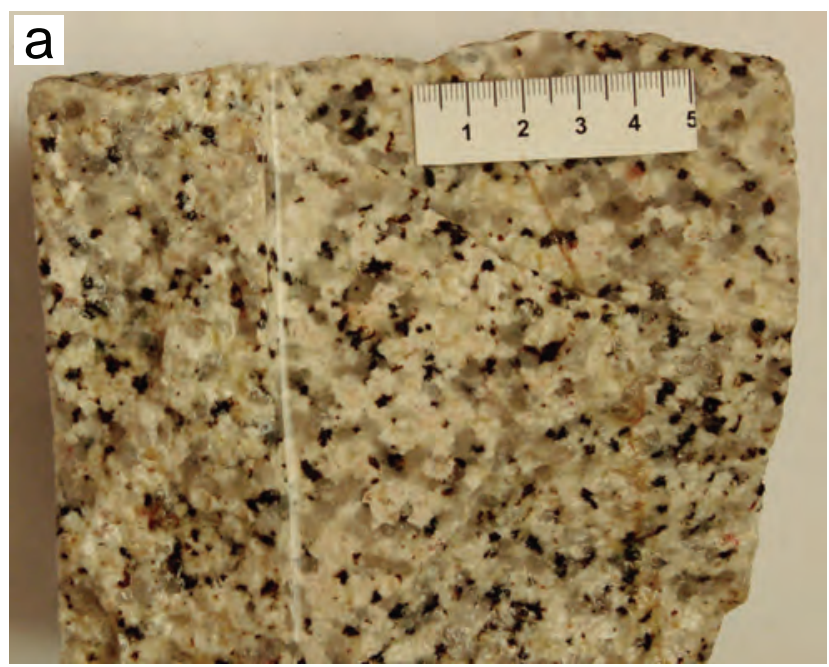

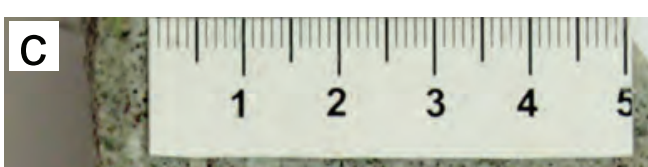
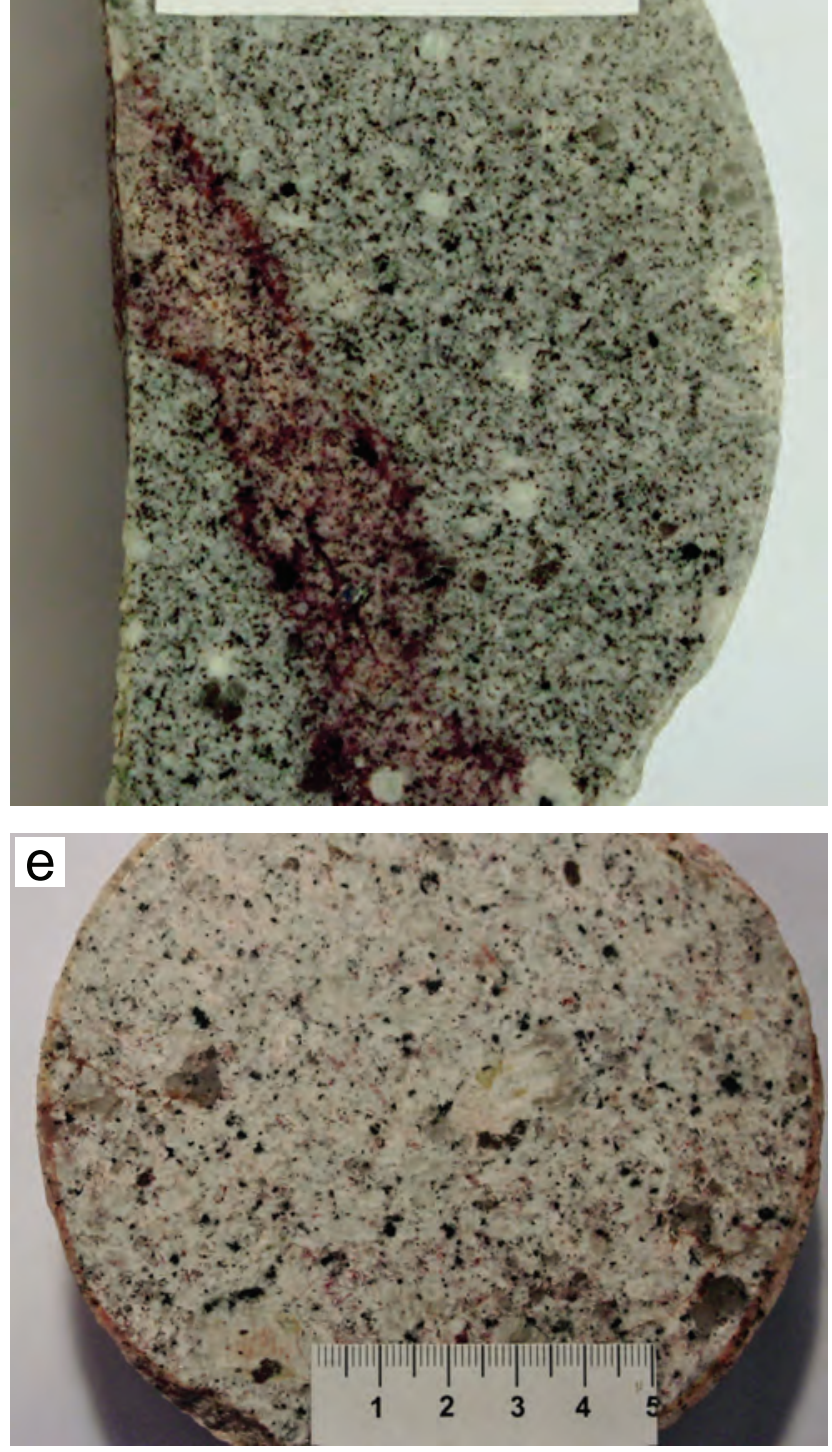
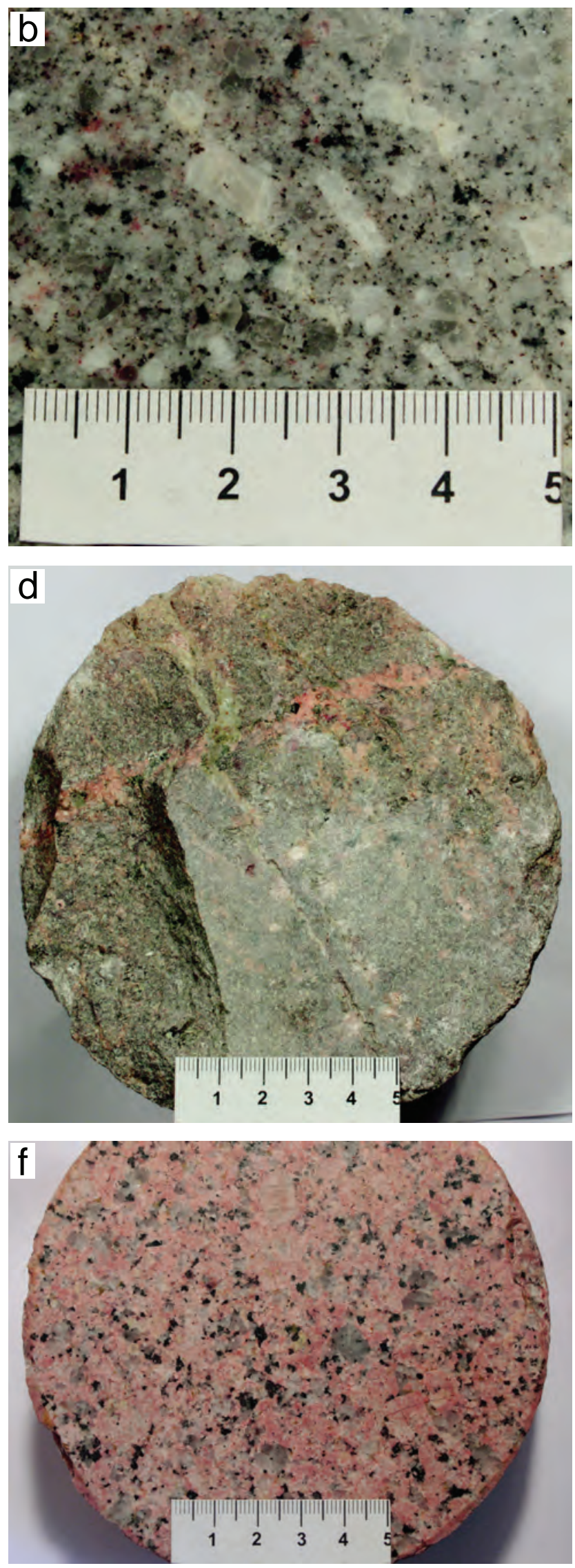
ets, several $\mathrm{cm}$ in size, formed by orthoclase, quartz and lithian annite. The granite is composed of quartz (32-52 vol. \%), orthoclase (19-33\%), albite (20-27\%) and lithian annite (2-6\%) with accessoric zircon, xenotime, monazite, thorite, rutile, columbite, pyrochlore, synchesite and fluorite (Rub et al. 1998; Johan and Johan 2005; Fig. 3), secondary minerals are hematite, calcite, sericite and kaolinite.

\subsection{Porosity and density data}

Density (dry and wet bulk density, grain density) and porosity were measured on 58 samples by Chlupáčová and Štemprok (1965). The changes in these properties are shown in Fig. 5. Average wet bulk density of the granite variants is $2.58 \mathrm{~g} / \mathrm{cm}^{3}$, of medium-grained zinnwaldite granite $2.59 \mathrm{~g} / \mathrm{cm}^{3}$ and of the porphyritic medium-grained granite, predominant in the lower suite $2.57 \mathrm{~g} / \mathrm{cm}^{3}$. In alteration zones these values are lowered e.g. to $2.38 \mathrm{~g} /$ $\mathrm{cm}^{3}$ at depth of $588 \mathrm{~m}$, to $2.3 \mathrm{~g} / \mathrm{cm}^{3}$ at $841 \mathrm{~m}$ and to 2.36 $\mathrm{g} / \mathrm{cm}^{3}$ at $1259 \mathrm{~m}$. On the contrary, in greisens the bulk density is slightly increased to $2.84 \mathrm{~g} / \mathrm{cm}^{3}$. The increased porosity is located in the upper part of the cupola, where substantial phyllic alteration has occurred. The porosity below the ore zone is lowered to $\sim 1 \%$; its increase over $8 \%$ is related to zones of fracturing and alteration by

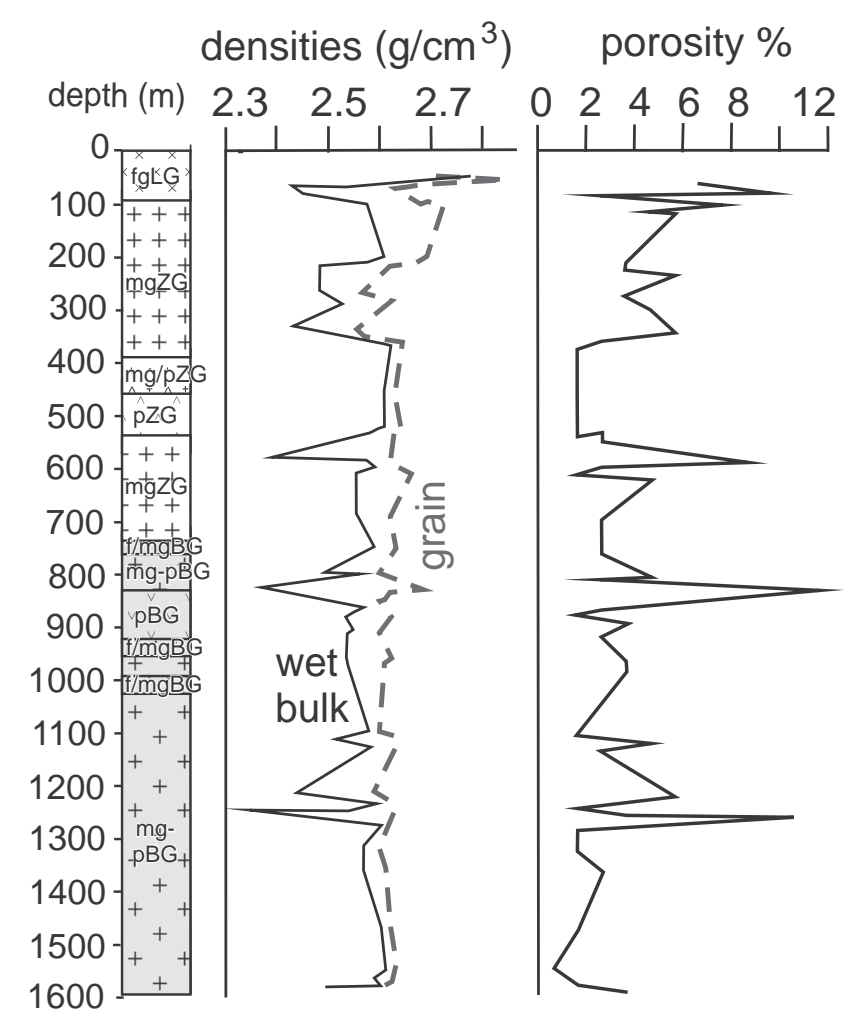

Fig. 5 Wet bulk and grain densities and porosity in the granites from the drill core CS-1 (data of Chlupáčová and Štemprok 1965). circulating fluids (connected mainly with sericitization and kaolinization) at c. $600 \mathrm{~m}, 820 \mathrm{~m}$ and $1250 \mathrm{~m}$ depth.

\subsection{Metasomatic and ore bodies}

The drill core of CS-1, numerous shallow drillings in the Cínovec mine area and underground mine workings (Štemprok 1965) encountered minor flat bands of albitites several $\mathrm{cm}$ thick throughout the whole upper suite, as well as several granitic zones enriched in K-feldspar and albite from 0.7 to $5 \mathrm{~m}$ thick underlying the ore zone at a depth from 270 to $369 \mathrm{~m}$. A single zoned minor body of pegmatite was found from 308.4 to $309.8 \mathrm{~m}$ depth composed of coarse grained quartz, Li-mica, K-feldspar and aplitic bands.

The $\mathrm{Sn}-\mathrm{W}$ mineralization is hosted by a system of flat and steeply inclined veins, wall-rock greisens and greisen lenses at the top of the cupola. Flat quartz veins encircle the inner contact of the granite cupola with the Teplice rhyolite and are accompanied by greisens of various shapes and sizes (Čabla and Tichý 1965; Štemprok et al. 1994; Seltmann et al. 1998). Steep veins, which strike predominantly NE-SW or N-S, and dip $80^{\circ}$ towards the $\mathrm{SE}$, are seen both in the granite and in the host Teplice rhyolite. The effect of massive argillitic alteration can be traced down to $c$. $150 \mathrm{~m}$ depth in the center of the cupola.

\subsection{The age of the granites and greisens}

The granites of the Older Intrusive Complex (OIC) of the KHEB have not been found in the mine area, the nearest body assigned to the OIC is the Fláje Massif c. $10 \mathrm{~km}$ to the west of Cínovec (Fig. 1; Štemprok et al. 2003). The ages of Younger Intrusive Complex (YIC) granites in the Eastern Krušné hory/Erzgebirge dated by standard geochronological methods are uncertain due to highly evolved nature of the granites, their repeated hydrothermal overprint, multiple fault reactivation and regional thermal reequilibration in the Mesozoic times (Gerstenberger 1989; Romer et al. 2007, 2010a). The maximum intrusion age of the Li-F and P-poor granites in the Eastern Erzgebirge, unaffected by $\mathrm{Sn}-\mathrm{W}$ mineralization, is constrained by $\mathrm{U}-$ $\mathrm{Pb}$ zircon dating of the microgranite from Písečný vrch at $319 \pm 2 \mathrm{Ma}$ (Romer et al. 2010b).

The K-Ar dating of trioctahedral micas separated from the granite samples of the drill core CS-1 was done in the Czech Geological Survey, Prague in 1964 (V. Šmejkal, H. Mašková) It determined the age of zinnwaldite from a depth of $498.5 \mathrm{~m}$ at $290 \mathrm{Ma}$, and from a depth of $647.6 \mathrm{~m}$ at $295 \mathrm{Ma}$. The samples of lithian annite from a depth of $887.3 \mathrm{~m}$ yielded an age of $325 \mathrm{Ma}$, and from the 1246 m 316 Ma. These values were recalculated by Dolejš and Štemprok (2001) using decay constants provided by Steiger and Jäger (1977) as 281-286 Ma for zinnwaldite 
granite, and 306-312 Ma for lithian annite granite. Intrusion ages lower than $300 \mathrm{Ma}$ do not agree with the Re-Os ages for molybdenite from Altenberg granites $(318 \pm 2$ and $324 \pm 3$ Ma: Romer et al. 2007). These age determinations are, however, supported by new molybdenite Re-Os dating from the Krupka ore district. Two samples from the Knötel Mo deposit yielded 319.2 \pm 2.0 and 317.7 $\pm 2.0 \mathrm{Ma}$, and a single one from the Preiselberk Sn deposit $315 \pm 2.3 \mathrm{Ma}$ (Ackerman et al. in print).

Seven Li-mica separates from the greisens of Zinnwald were dated by $\mathrm{Ar}-\mathrm{Ar}$ method at Argonlab Freiberg (ALF) using the laser step-heating technique. The ages, interpreted as near-formation ages of Li-mica, ranged between $312.6 \pm 2.1$ and $314.9 \pm 2.3 \mathrm{Ma}$ (Seifert et al. 2011). Two new ages obtained by the same method from the Zinnwald quartz-mica greisen are 311.4 \pm 3.0 and 312.5 $\pm 3.1 \mathrm{Ma}$ (Seifert and Pavlova 2016).

\section{Sampling and methods used}

The drill core of CS-1 stored in the core repository of the Czech Geological Survey in Chotěboř has been sampled in several campaigns (Štemprok 1965; Rub et al. 1983; Johan and Johan 2005; Breiter et al. 2015a). The first was done in 1963-1965 by collecting 193 samples (c. 0.5-3 $\mathrm{kg}$ each), subjected to detailed petrological examination (Štemprok 1965). Sections of the drill core revealing the contacts between the textural variants have been cut and polished, documented by macrophotographs and examined using binocular microscope. In total, 295 thin sections have been prepared from the whole drill core, most of which have been re-examined in the present study.

Silicate analyses evaluated here were published by Štemprok and Šulcek (1969), Rub et al. (1983), Cocherie et al. (1991), Rub et al. (1998), Dolejš and Štemprok (2001), Rykl and Štemprok (1992) and Breiter and Škoda (2012). Most of them have been carried out at the Czech Geological Survey, Prague (CGS) by classical wet chemical methods. A systematic sampling of the drill core for chemical analyses was done on samples of $c .10 \mathrm{~kg}$ mass collected mostly in $10 \mathrm{~m}$ intervals (Štemprok and Šulcek 1969). The powders from these samples were used for analyses of Sn and Be, completed by optical emission spectroscopy (OES) at CGS (detection limit for Sn 2 ppm, for Be 1 ppm; Weiss 1983) and the results are interpreted in this paper (Electronic Supplementary Material 1).

The samples at c. 100-300 m intervals were analyzed by X-ray fluorescence method (XRF; Ti, Fe, Rb, Ba, $\mathrm{As}, \mathrm{Bi}, \mathrm{Sn}, \mathrm{W}, \mathrm{Zn}, \mathrm{Pb}, \mathrm{Cu}, \mathrm{U}, \mathrm{Zr}, \mathrm{Y}, \mathrm{Nb}, \mathrm{Mo}, \mathrm{Ag}$ ) in the chemical laboratory of Geoindustria, Prague-Černošice (Tab. 1). A separate set of 46 samples was analyzed for $\mathrm{U}$, Th, $\mathrm{U}_{\text {eq. }}$ and $\mathrm{K}$ in Geofyzika Brno on a laboratory

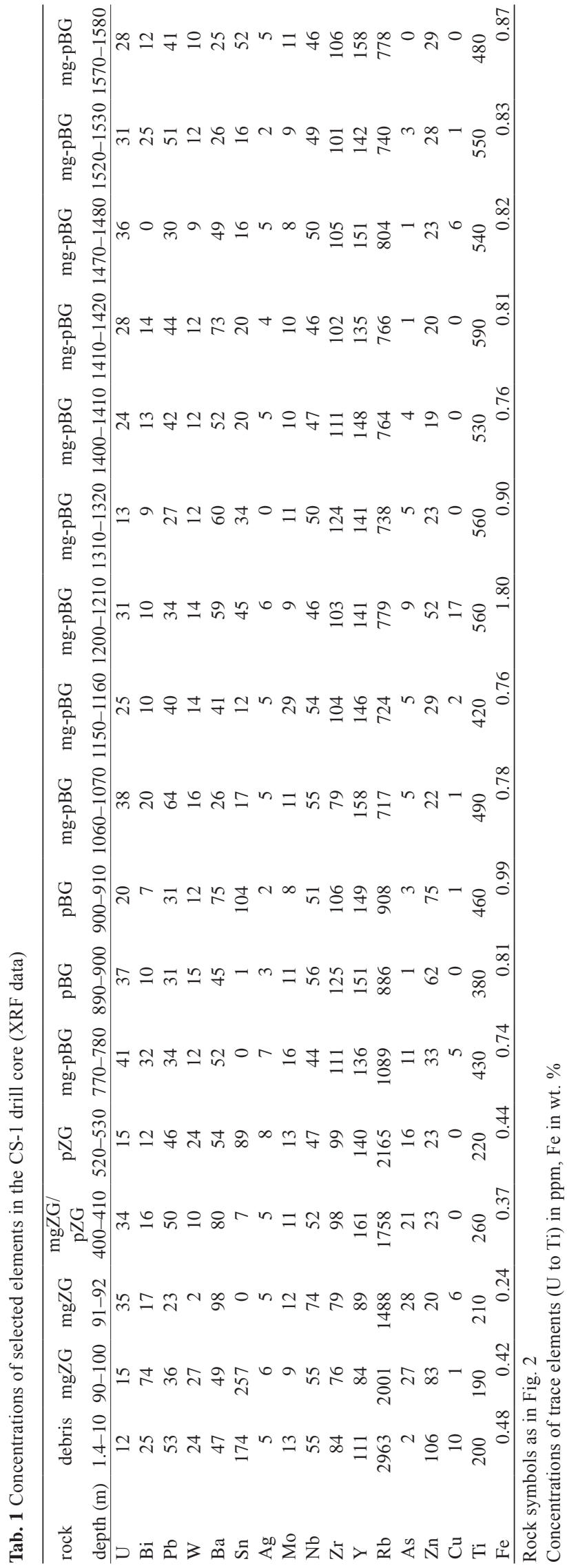


Tab. 2 Radiometric analyses of the samples from the CS-1 drill core

\begin{tabular}{|c|c|c|c|c|c|c|}
\hline depth & rock & Th ppm & U ppm & K wt. \% & $\mathrm{Th} / \mathrm{U}$ & $\mathrm{U}_{\text {eq. }} \mathrm{ppm}$ \\
\hline 78.0 & fgLG & 13.0 & 8.3 & 3.1 & 1.6 & 16.2 \\
\hline 209.7 & $\mathrm{mgZG}$ & 30.0 & 11.6 & 1.3 & 2.6 & 24.2 \\
\hline 232.9 & $\mathrm{mgZG}$ & 31.0 & 18.4 & 3.0 & 1.7 & 32.8 \\
\hline 297.0 & $\mathrm{mgZG}$ & 21.6 & 10.2 & 4.0 & 2.1 & 22.2 \\
\hline 356.3 & $\operatorname{mgZG}$ & 11.2 & 8.3 & 5.1 & 1.3 & 17.5 \\
\hline 358.0 & flsp & 7.6 & 5.5 & 7.3 & 1.4 & 15.5 \\
\hline 372.6 & $\mathrm{pZG}$ & 32.6 & 19.6 & 3.1 & 1.7 & 34.7 \\
\hline 420.0 & mgZG & 23.7 & 20.6 & 4.9 & 1.2 & 34.2 \\
\hline 466.6 & $\mathrm{pZG}$ & 29.0 & 17.2 & 5.1 & 1.7 & 33.0 \\
\hline 518.0 & $\mathrm{pZG}$ & 39.2 & 29.6 & 4.2 & 1.3 & 48.3 \\
\hline 529.5 & $\mathrm{pZG}$ & 38.4 & 23.2 & 2.9 & 1.7 & 40.3 \\
\hline 529.8 & mgZG & 14.3 & 37.4 & 3.7 & 0.4 & 46.4 \\
\hline 531.1 & $\mathrm{mgZG}$ & 30.2 & 12.0 & 4.1 & 2.5 & 27.2 \\
\hline 531.7 & $\mathrm{mgZG}$ & 25.5 & 17.2 & 4.0 & 1.5 & 30.6 \\
\hline 535.9 & $\mathrm{mgZG}$ & 23.5 & 33.6 & 4.0 & 0.7 & 46.3 \\
\hline 537.3 & $\mathrm{mgZG}$ & 28.3 & 30.1 & 3.7 & 0.9 & 44.2 \\
\hline 587.6 & $\mathrm{mgZG}$ & 24.4 & 54.6 & 4.2 & 0.4 & 67.8 \\
\hline 611.0 & $\mathrm{mgZG}$ & 28.0 & 16.1 & 4.2 & 1.7 & 30.6 \\
\hline 698.0 & mgZG & 33.3 & 36.5 & 4.1 & 0.9 & 52.9 \\
\hline 754.1 & mg-pBG & 44.2 & 42.4 & 4.0 & 1.0 & 62.7 \\
\hline 763.5 & mg-pBG & 40.9 & 18.4 & 4.3 & 2.2 & 37.8 \\
\hline 784.7 & mg-pBG & 38.1 & 17.1 & 3.0 & 2.2 & 34.2 \\
\hline 790.0 & $m g-p B G$ & 50.2 & 12.5 & 4.0 & 4.0 & 35.2 \\
\hline 836.1 & pBG & 62.6 & 36.5 & 5.1 & 1.7 & 64.7 \\
\hline 866.0 & pBG & 58.6 & 37.6 & 4.7 & 1.6 & 63.9 \\
\hline 930.0 & mg-pBG & 61.2 & 20.4 & 5.0 & 3.0 & 48.0 \\
\hline 956.7 & mg-pBG & 65.0 & 13.9 & 4.0 & 4.7 & 41.9 \\
\hline 977.9 & mg-pBG & 61.1 & 22.9 & 4.3 & 2.7 & 49.8 \\
\hline 978.0 & mg-pBG & 65.0 & 24.0 & 4.1 & 2.7 & 52.1 \\
\hline 983.9 & mg-pBG & 58.6 & 10.2 & 4.2 & 5.7 & 36.0 \\
\hline 1014.1 & mg-pBG & 69.1 & 24.1 & 3.3 & 2.9 & 52.9 \\
\hline 1113.9 & mg-pBG & 58.2 & 29.3 & 3.5 & 2.0 & 54.3 \\
\hline 1121.0 & mg-pBG & 60.1 & 16.3 & 4.8 & 3.7 & 43.3 \\
\hline 1183.0 & pBG & 60.3 & 18.8 & 3.8 & 3.2 & 44.9 \\
\hline 1195.5 & mg-pBG & 62.5 & 16.1 & 4.6 & 3.9 & 43.8 \\
\hline 1223.8 & mg-pBG & 54.9 & 39.1 & 4.2 & 1.4 & 63.6 \\
\hline 1225.0 & mg-pBG & 62.3 & 18.0 & 4.1 & 3.5 & 45.1 \\
\hline 1256.2 & mg-pBG & 53.3 & 16.1 & 3.9 & 3.3 & 39.7 \\
\hline 1260.6 & mg-pBG & 49.1 & 14.1 & 3.6 & 3.5 & 35.8 \\
\hline 1344.9 & mg-pBG & 56.8 & 25.8 & 4.0 & 2.2 & 50.8 \\
\hline 1368.9 & mg-pBG & 50.8 & 18.8 & 4.2 & 2.7 & 41.8 \\
\hline 1415.0 & mg-pBG & 66.5 & 31.0 & 4.2 & 2.1 & 59.8 \\
\hline 1440.9 & mg-pBG & 54.9 & 20.9 & 3.4 & 2.6 & 44.6 \\
\hline 1466.8 & mg-pBG & 55.1 & 26.0 & 3.3 & 2.1 & 49.6 \\
\hline 1479.2 & mg-pBG & 53.1 & 28.9 & 4.0 & 1.8 & 52.5 \\
\hline 1593.0 & pBG & 79.7 & 36.4 & 4.9 & 2.2 & 70.7 \\
\hline
\end{tabular}

Rock symbols as in Fig. 2

flsp $=\mathrm{K}$-feldspar-enriched granites

gamma-ray spectrometer with a scintillation detector and is also presented and interpreted in this paper (Tab. 2).

New systematic sampling of the drill core has been done in 2014-2015 by the CGS staff with 254 samples taken for trace-element analyses and mineral-composition studies (Rambousek and Knésl 2015; Breiter et al. 2015a, b).
Tab. 3 Silicate analyses of granites from the mica transition zone of the CS-1 drill core (724.6-8 m depth) (in wt.\%)

\begin{tabular}{lrr}
\hline granite type & microgranite & medium-grained \\
sample & $321 / 1$ & $321 / 2$ \\
\hline $\mathrm{SiO}_{2}$ & 76.46 & 75.32 \\
$\mathrm{TiO}_{2}$ & 0.03 & 0.02 \\
$\mathrm{Al}_{2} \mathrm{O}_{3}$ & 12.98 & 14.16 \\
$\mathrm{Fe}_{2} \mathrm{O}_{3}$ & 0.52 & 0.46 \\
$\mathrm{FeO}$ & 0.67 & 0.60 \\
$\mathrm{MnO}$ & 0.05 & 0.04 \\
$\mathrm{MgO}$ & 0.04 & 0.04 \\
$\mathrm{CaO}$ & 0.47 & 0.41 \\
$\mathrm{Na}_{2} \mathrm{O}$ & 3.46 & 4.03 \\
$\mathrm{~K}_{2} \mathrm{O}$ & 4.20 & 3.89 \\
$\mathrm{P}_{2} \mathrm{O}_{5}$ & 0.01 & 0.01 \\
$\mathrm{H}_{2} \mathrm{O}^{-}$ & 0.10 & 0.01 \\
$\mathrm{H}_{2} \mathrm{O}^{+}$ & 0.27 & 0.31 \\
$\mathrm{CO}_{2}$ & 0.15 & 0.21 \\
$\mathrm{~F}$ & 0.62 & 0.61 \\
sum & 100.03 & 100.12 \\
$-\mathrm{F}$ eq. & 0.26 & 0.26 \\
\hline Sum & 99.77 & 99.86 \\
\hline
\end{tabular}

Two new chemical analyses examined the composition of the medium-grained and porphyritic microgranite in mutual contact at a depth of $\sim 725 \mathrm{~m}$, within the transition zone between the upper and lower suite granites. They were carried out at the Faculty of Science, Charles University in Prague by wet chemical methods (Tab. 3) and by ICP-MS analysis (Tab. 4). The trace-element analyses were done after modified total digestion in mineral acids $\left(\mathrm{HF}+\mathrm{HClO}_{4}\right)$ and borate fusion $\left(\mathrm{Na}_{2} \mathrm{CO}_{3}+\mathrm{Na}_{2} \mathrm{~B}_{4} \mathrm{O}_{7}\right)$ in Pt crucibles. Fluorine concentrations were determined by ion selective electrode, Sn and Mo by XRF and As by atomic absorption with generation of hydrides (HGAAS) at CGS.

The electron-microprobe analyses of albite and $\mathrm{Li}-\mathrm{Fe}$ micas were completed on a Jeol microprobe JXA-8530F, equipped with five WDS spectrometers at the Faculty of Science, Charles University in Prague. Measurements were carried out with an accelerating voltage of $15 \mathrm{kV}$, beam current of $20 \mathrm{nA}$, beam diameter of $5 \mu \mathrm{m}$ and the acquisition time of 30-60 s. ZAF correction procedure was used.

\section{Textural variants of the granites}

\subsection{Textural variants of granites in the CS-1 drill core}

Contacts between the textural variants in both the upper and lower granite suites were examined in new studies of the CS-1 drill core. Microgranites ( $<1 \mathrm{~mm}$ grain size) are frequently enclosed in predominant medium-grained 
Tab. 4 Trace-element analyses of granites from the mica transition zone of the CS-1 drill core (724.6-8 m depth) (in ppm)

\begin{tabular}{|c|c|c|}
\hline granite type & microgranite & medium-grained \\
\hline sample & $321 / 1$ & $321 / 2$ \\
\hline $\mathrm{Li}$ & 377.67 & 479.47 \\
\hline $\mathrm{Be}$ & 11.46 & 11.34 \\
\hline Sc & 7.10 & 7.28 \\
\hline $\mathrm{V}$ & 3.42 & 2.90 \\
\hline $\mathrm{Cr}$ & $<0.5$ & $<0.5$ \\
\hline Co & 0.27 & 0.11 \\
\hline $\mathrm{Ni}$ & $<0.5$ & $<0.5$ \\
\hline $\mathrm{Cu}$ & 1.91 & 2.73 \\
\hline Zn & 16.78 & 17.91 \\
\hline $\mathrm{Ga}$ & 28.22 & 32.63 \\
\hline $\mathrm{Rb}$ & 1193.85 & 1092.85 \\
\hline $\mathrm{Sr}$ & 5.81 & 3.75 \\
\hline $\mathrm{Y}$ & 153.84 & 80.68 \\
\hline $\mathrm{Zr}$ & 114.16 & 89.33 \\
\hline $\mathrm{Nb}$ & 68.63 & 88.22 \\
\hline $\mathrm{Sb}$ & 0.11 & 0.25 \\
\hline Cs & 28.47 & 43.17 \\
\hline $\mathrm{Ba}$ & 27.89 & 18.72 \\
\hline $\mathrm{Hf}$ & 9.94 & 8.99 \\
\hline Тa & 7.69 & 11.03 \\
\hline $\mathrm{Tl}$ & 5.48 & 5.07 \\
\hline Sn & 36 & 24 \\
\hline Mo & $<1$ & 3 \\
\hline $\mathrm{Pb}$ & 46.19 & 46.62 \\
\hline As & 3.96 & 13.63 \\
\hline $\mathrm{Bi}$ & 0.25 & 0.83 \\
\hline Th & 39.89 & 29.66 \\
\hline $\mathrm{U}$ & 31.66 & 60.59 \\
\hline $\mathrm{La}$ & 40.01 & 31.33 \\
\hline $\mathrm{Ce}$ & 107.14 & 86.21 \\
\hline $\operatorname{Pr}$ & 12.71 & 10.34 \\
\hline $\mathrm{Nd}$ & 42.07 & 32.74 \\
\hline Sm & 12.88 & 10.11 \\
\hline $\mathrm{Eu}$ & 0.01 & 0.01 \\
\hline Gd & 13.65 & 9.88 \\
\hline $\mathrm{Tb}$ & 3.02 & 2.23 \\
\hline Dy & 22.4 & 16.27 \\
\hline Ho & 4.82 & 3.21 \\
\hline Er & 17.13 & 11.45 \\
\hline $\mathrm{Tm}$ & 3.14 & 2.08 \\
\hline $\mathrm{Yb}$ & 24.61 & 16.65 \\
\hline $\mathrm{Lu}$ & 3.67 & 2.39 \\
\hline
\end{tabular}

granite (c. 1 to $5 \mathrm{~mm}$ ) as enclaves or minor bodies ( $\mathrm{dm}$ to $\mathrm{m}$ sizes), in places characterized by alternation of medium-grained granites and microgranites of $\mathrm{dm}$ up to tens of $m$ thicknesses (Fig. 2).

Enclaves of microgranites varying from $\mathrm{cm}$ to $\mathrm{dm}$ sizes have been encountered in the medium-grained zinnwaldite granite. For instance, at depth of $399.2 \mathrm{~m}$ their contact was gradational (Fig. 6a) but at a depth of $594.2 \mathrm{~m}$ (Fig. 6b) it was sharp. An albite-rich groundmass penetrates from the medium-grained zinnwaldite granite into the microgranite.
In the lower granite suite, enclaves of lithian annite microgranites have been observed in several sections of the drill core, e.g. at $1339.8 \mathrm{~m}$ (Fig. 6c). A microgranite enclave, $c$. $0.5 \mathrm{~m}$ across, is enclosed by medium-grained lithian annite granite and separated by a sharp contact from the hosting pink medium-grained granite. The contact is accentuated by postmagmatic hematitisation.

A fine-grained lithian annite granite hosts accumulation of 3-5 mm K-feldspar crystals, with lithian annite in aggregates and /or single grains up to $7 \mathrm{~mm}$ size. These are accompanied by smaller quartz and albite grains in aggregates up to $3 \mathrm{~mm}$; all forming irregular schlieren in microgranite (Fig. 6d). The uneven distribution of feldspar- and mica-rich groundmass (Fig. 6e) is a typical feature of some porphyritic medium-grained lithian annite granites, hence termed "mixed granites" in earlier petrographic studies (Štemprok 1965). At $1591.0 \mathrm{~m}$, a band of K-feldspar (Fig. 6f) with large crystals of lithian annite transects the porphyritic medium-grained granite, documenting a possible origin for red K-feldspar-rich granites by a later K-feldspar growth.

\subsection{Textural variants in the contact zone between the upper and lower suite}

The textural variants in the transition zone at a depth of $c .725 \mathrm{~m}$ between the zinnwaldite and lithian annite granites, i.e. between the upper and lower suites, have been examined regarding their modal composition and mineral chemistry. Microgranites and medium-grained granites form a zone c. $25 \mathrm{~m}$ thick which consists of an alternation of variously sized bodies of microgranites and medium-grained granites. Contact between the uppermost microgranite and the overlying predominant medium-grained granite (Fig. 7a-b) is sharp and marked by single grains or aggregates of K-feldspar and quartz grains up to $5 \mathrm{~mm}$ surrounded by an albite-rich groundmass of $c .3 \mathrm{~mm}$ grain size, which produces an irregular border line with the microgranite. Two variants examined chemically are as follows:

\subsubsection{Weakly porphyritic microgranite}

The earlier microgranite is a dark grey fine-grained rock with rare phenocrysts of K-feldspar and quartz. It consists of perthitic K-feldspar ( 26 vol. \%), albite $(\sim 30 \%)$, quartz $(\sim 40 \%)$, and lithian annite ( 4 vol. $\%)$ in a texture resembling a two-phase granitic one (Fig. 8a). Quartz phenocrysts $(<5 \mathrm{~mm})$ consist of a single or several aggregated grains, with additional quartz crystals $(0.1-0.5 \mathrm{~mm})$ attached at the margins in optical continuity with the large quartz grain. K-feldspar is strongly perthitic (Fig. 8b), occasionally with 

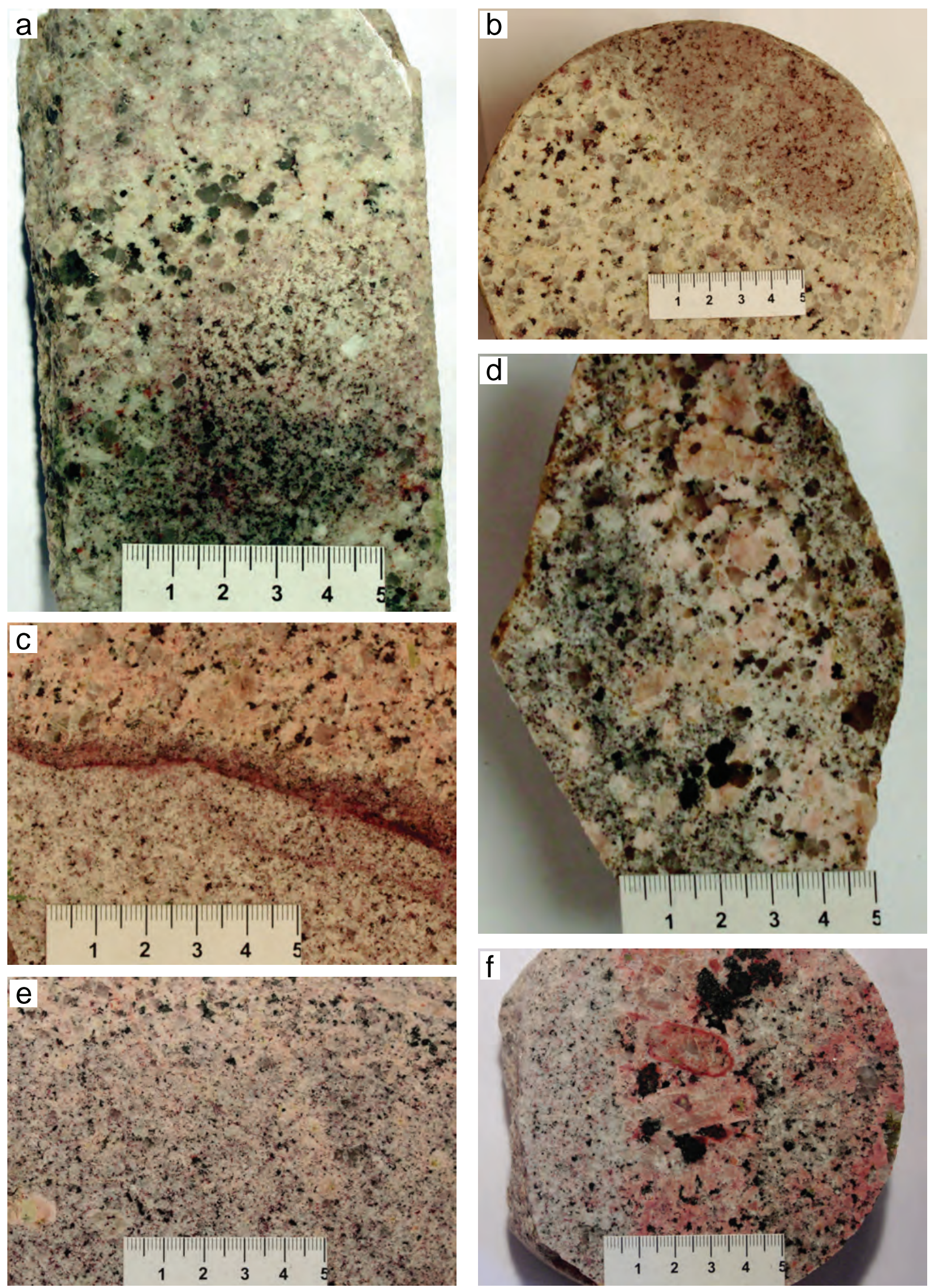

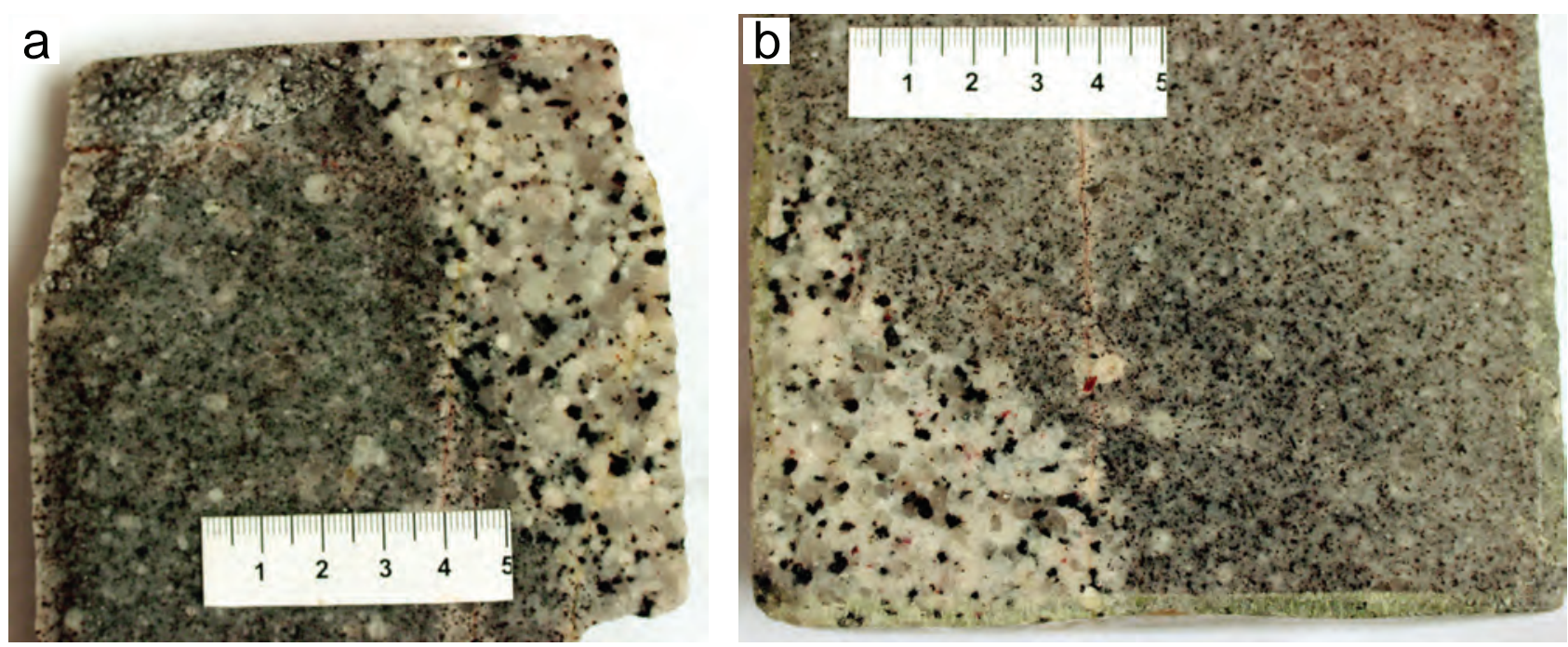

Fig. 7 Steep (a) and flat (b) contacts between medium-grained lithian annite granite and lithian annite microgranite at a depth of $724.6-8 \mathrm{~m}$.

$\sim 1 \mathrm{~mm}$ thick zones of micropegmatitic intergrowths and quartz inclusions (Fig. 8c). The groundmass of the granite consists of the grains of two main grain sizes: c. $0.1-0.5 \mathrm{~mm}$ and c. $0.01-0.1 \mathrm{~mm}$. The fine-grained groundmass occurs in interstices of the larger grains and strongly resembles the granites from the Karlovy Vary Pluton (Štemprok et al. 2008). K-feldspar in larger grains contains intergrowths of secondary albite, as irregular patches around grain margins or irregular inner zones. Albite forms anhedral grains with a dense polysynthetic twinning. Lithian annite occurs mostly in skeletal crystals (Fig. 8d) which enclose rounded quartz and feldspar grains from the groundmass. Lithian annite is pleochroic ( $\alpha$ and $\beta$ - colorless or very pale green, $\gamma$ - light greenish brown) with numerous darker pleochroic haloes along cleavage planes or at grain margins. A significant petrogenetic feature is the replacement of K-feldspar along cleavage by fine Li-Fe mica growths suggesting that this mica crystallized after the K-feldspar was formed. Mutual contacts of quartz grains are characterized by highly irregular locked boundaries. The lithian annite granite contains

Fig. 6 Contacts between microgranites and medium-grained granites: a - gradational transition of a microgranite enclave into albite-rich, medium-grained zinnwaldite granite (depth $399.2 \mathrm{~m}$ ); b - enclave of zinnwaldite microgranite enclosed in seriate medium-grained zinnwaldite granite with albitic groundmass penetrating into the microgranite $(594.2 \mathrm{~m})$; c - flat sharp contact, accentuated by postmagmatic hematitisation, between a $0.5 \mathrm{~m}$ lithian annite microgranite enclave and the porphyritic medium-grained lithian annite granite (1339.8 m); d - dispersion of K-feldspar and lithian annite phenocrysts into a finegrained groundmass in a porphyritic lithian annite microgranite (757.2 $\mathrm{m}) ; \mathbf{e}$ - coarsened ground-mass texture in a medium-grained, porphyritic lithian annite granite $(1244.5 \mathrm{~m}) ; \mathbf{f}$ - K-feldspar-rich band with large crystals of lithian annite intersecting a medium-grained lithian annite porphyritic granite $(1591.0 \mathrm{~m})$. accessory fluorite, topaz, zircon, xenotime, columbite, REE fluorides and uraninite as shown by electronmicroprobe analyses.

\subsubsection{Seriate medium-grained granite}

This younger white-grey equigranular rock consists of perthitic K-feldspar ( $\sim 24$ vol. \%), albite $(\sim 35 \%)$, quartz ( $\sim 37 \%)$ and lithian annite ( $\sim \%$ ), together with accessory topaz, fluorite, zircon, REE fluorides, columbite and bastnäsite. Quartz is anhedral, occurring in single grains (1-5 mm) or aggregates of several grains, in places with very weak undulose extinction; inclusions of feldspar of $0.05 \mathrm{~mm}$ sizes are rare. Many mica crystals are skeletal and enclose vicinal quartz or feldspar crystals and penetrate into K-feldspar grains along cleavage planes (Fig. 8e). Albite (An $<5$, Fig. 8f) in thick tabular crystals $(0.5-2 \mathrm{~mm})$ is densely twinned and forms single grains or aggregates which fill the interstices between quartz and K-feldspar crystals. The Li-Fe mica also forms thick tabular crystals 0.5 to $1 \mathrm{~mm}$ across (Fig. 8f) which are weakly pleochroic ( $\alpha$ and $\beta$ - colorless or very pale greenish brown, $\gamma$ - light greenish brown) and contain common pleochroic haloes around inclusions or cleavage planes. K-feldspar is anhedral $(1-5 \mathrm{~mm})$ and perthitic in most grains, occurring as single or twinned crystals or in aggregates. Larger K-feldspar grains (Fig. 8g) include randomly orientated albite crystals. Some grain boundaries between K-feldspar grains are lined by marginal albite or by quartz crystals (Fig. 8h). Rare topaz is irregularly distributed as anhedral single grains or small aggregates of up to $0.5 \mathrm{~mm}$ size with characteristic fractures. Phyllic alterations are practically absent, but very faint secondary hematitisation has been noted in some fractured feldspar grains. 
a.s.

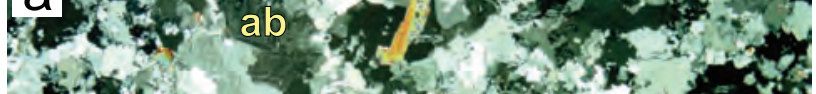

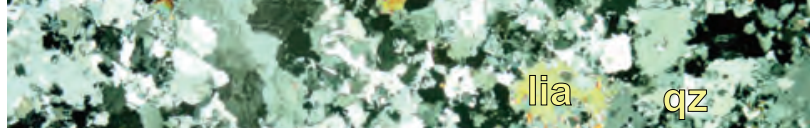

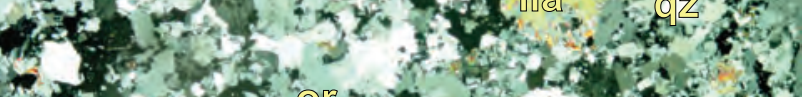

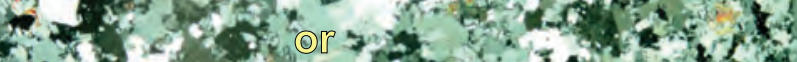

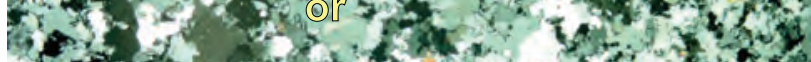

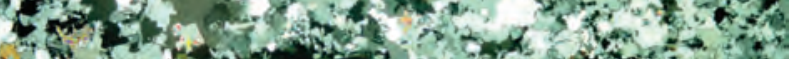

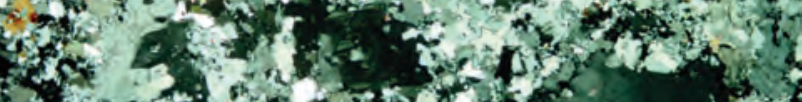

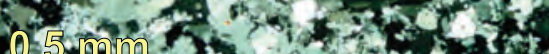

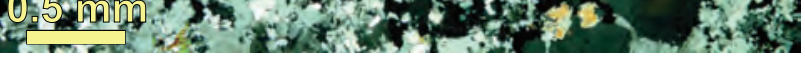
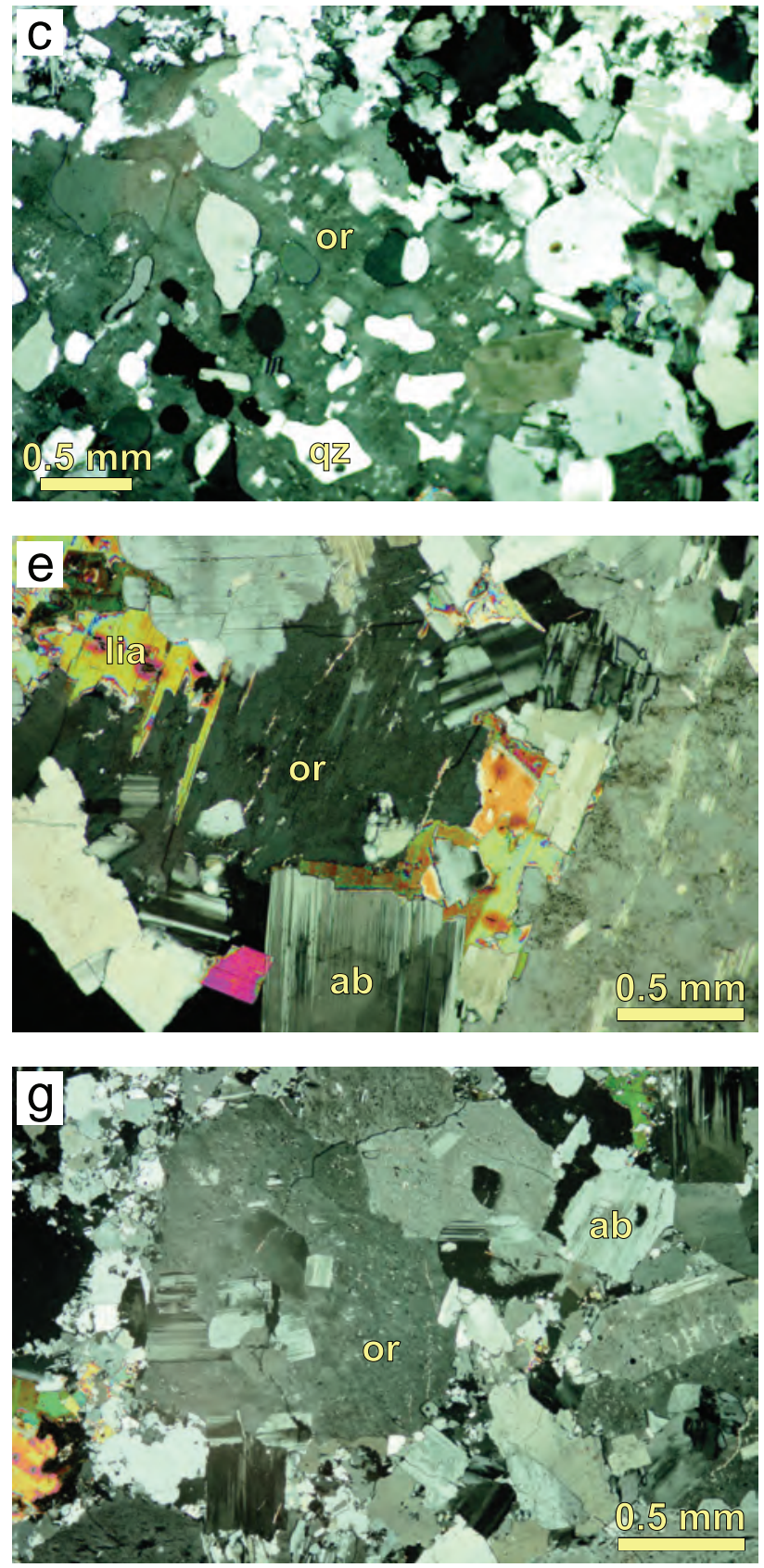

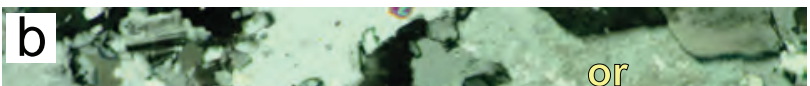
$4,8,4,0$ or

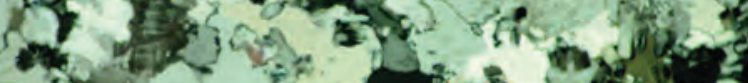

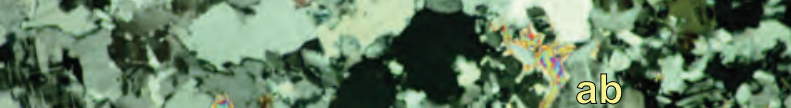

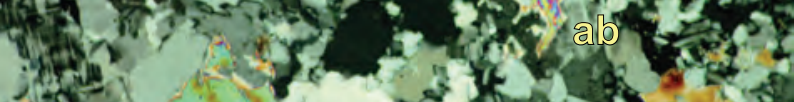

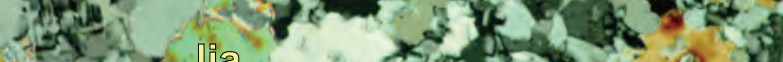

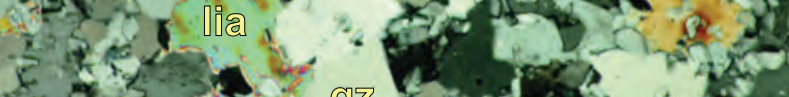

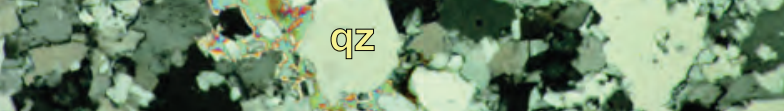

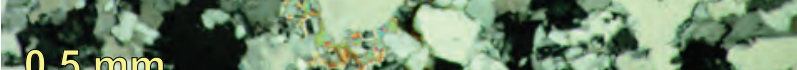

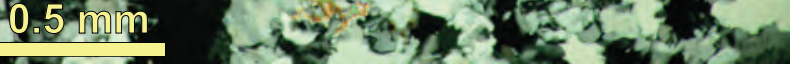
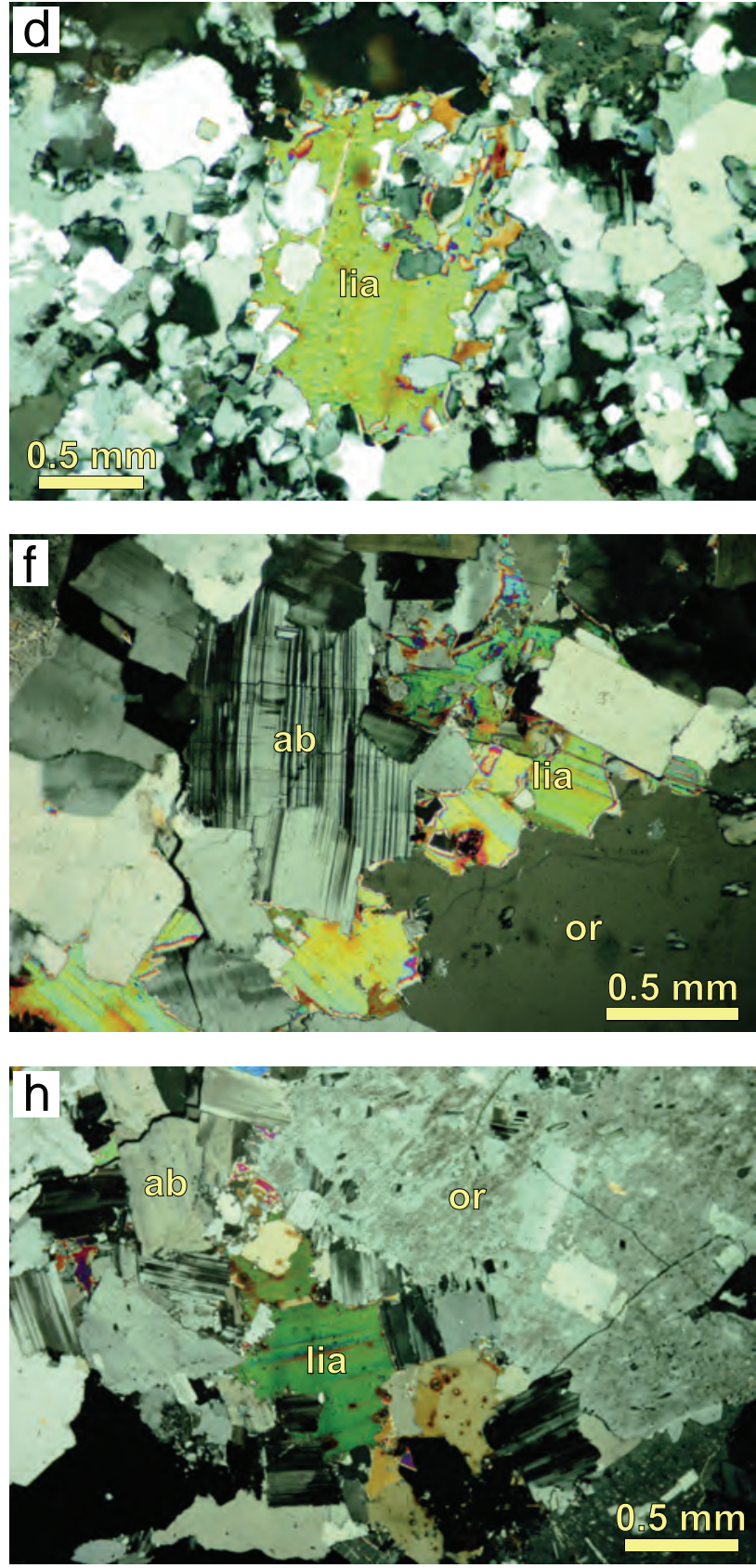


\section{Major and trace elements in rock-form- ing minerals in the CS-1 drill core}

\subsection{Quartz and feldspars}

Quartz contains up to $c .85 \mathrm{ppm} \mathrm{Ti}$ and to $c .400 \mathrm{ppm}$ $\mathrm{Al}$ in zinnwaldite granites and these amounts drop in greisens to $<10 \mathrm{ppm} \mathrm{Ti}$ and $<100 \mathrm{ppm} \mathrm{Al}$ (Breiter et al. 2015a). Microprobe analyses by Johan et al. (2012) found that plagioclase contains $91.1-99.6 \mathrm{~mol}$. \% Ab, 0-8.0 mol. \% An and 0-2.3 mol. \% Or. Analyses of albite from two textural variants at $725 \mathrm{~m}$ depth gave $97.9-98.4$ mol. \% Ab, 0.61-1.2 mol. \% An and 0.96-1.0 mol. \% Or. Orthoclase in lithian annite granites contains $0.24-0.48$ wt. \% and in zinnwaldite granites $0.62-0.83$ wt. $\% \mathrm{Rb}_{2} \mathrm{O}$ (Johan et al. 2012).

\subsection{Trioctahedral micas}

The composition and physical properties of Li-Fe micas from the Krušné hory/Erzgebirge have been examined in detail by Rieder et al. (1970), who found trioctahedral micas from the CS-1 drill core to have 3.18-3.80 wt. \% $\mathrm{Li}_{2} \mathrm{O}$ (at $609.0-609.8 \mathrm{~m}$ and $262.0-264.4 \mathrm{~m}$, respectively) and 1.25 wt. $\% \mathrm{Li}_{2} \mathrm{O}$ (from $778.5 \mathrm{~m}$ downwards). Trioctahedral micas from the upper granite suite of the CS-1 drill core have been classified as lepidolite and zinnwaldite, and from the lower granite suite as protolithionite (Rub et al. 1983, 1998). In the new IMA nomenclature of micas (Rieder et al. 1998) it was recommended that the name of protolithionite should be changed to zinnwaldite, lithian annite or lithian siderophyllite. Based on microprobe studies, Johan et al. (2012) concluded that the "protolithionite" mica in the CS-1 drill core should be referred to as lithian annite and this classification is used in the present paper.

The CS- 1 zinnwaldite accommodates 0.2 to 0.5 wt. $\% \mathrm{TiO}_{2}$ and lithian annite $0.3-1.3$ wt. $\% \mathrm{TiO}_{2}$ (Rub

\footnotetext{
Fig. 8 Photomicrographs of microgranite and medium-grained granites in contact at 724.6-8 $\mathrm{m}$ depth: a - weakly porphyritic lithian annite microgranite with the groundmass consisting of larger irregular grains with finer grains in interstices ( $a b$ - albite, lia - lithian annite, qz - quartz, or - orthoclase); $\mathbf{b}$ - detail of a two-phase granite texture in lithian annite microgranite; $\mathbf{c}$ - orthoclase phenocryst in the porphyritic lithian annite microgranite enclosing quartz crystals as rounded grains or rods; $\mathbf{d}$ - skeletal crystal of lithian annite enclosing quartz and feldspar crystals from the groundmass in porphyritic lithian annite microgranite; e - seriate medium-grained lithian annite granite with lithian annite flakes replacing orthoclase along cleavage planes; $\mathbf{f}$ - a slightly fractured albite crystal in seriate medium-grained lithian annite granite; $\mathbf{g}$ - perthitic orthoclase crystal in seriate medium-grained lithian annite granite embedding variously oriented albite crystals; $\mathbf{h}$ - orthoclase and lithian annite crystals in seriate medium-grained lithian annite granite surrounded by finer grains of albite and quartz.
}

wt. \%

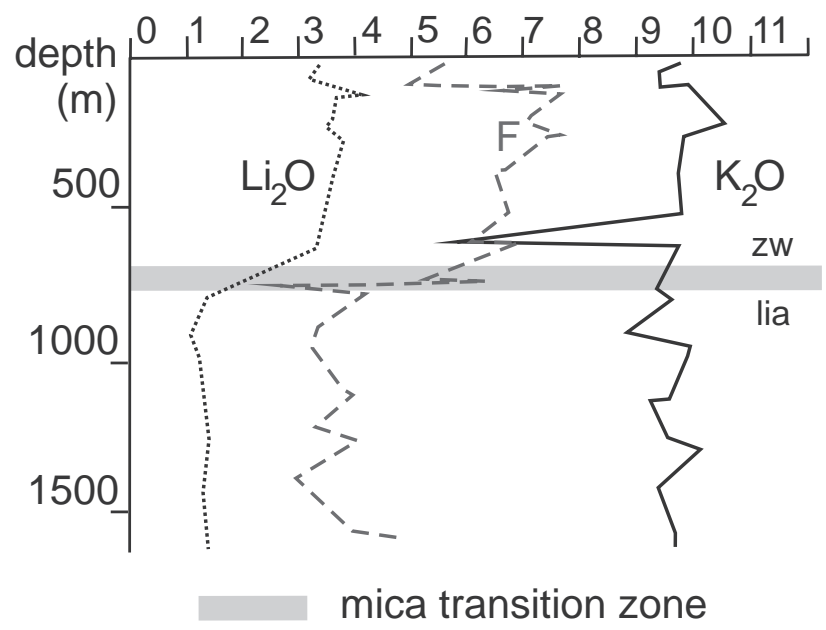

Fig. 9 Distribution of $\mathrm{K}, \mathrm{Li}$ and $\mathrm{F}$ in $\mathrm{Li}-\mathrm{Fe}$ micas from the analyses of mica concentrates in Rub et al. (1983) and electron-microprobe analyses by Johan et al. (2012).

et al. 1983; Johan et al. 2012). Breiter et al. (2015a) observed that the $\mathrm{SiO}_{2}$ concentrations in $\mathrm{Li}-\mathrm{Fe}$ micas change from 39 wt. \% in the lower suite to 48 wt. \% in the upper suite granites. Both micas show similar $\mathrm{K}_{2} \mathrm{O}$ concentrations of c. 9.5 wt. \% (Fig. 9; Tab. 5). The $\mathrm{Li}_{2} \mathrm{O}$ contents in zinnwaldite vary from 3 to $4 \mathrm{wt}$. $\%$, in lithian annite are c. 1 wt. \% (Rub et al. 1983). The transition from zinnwaldite to lithian annite granites is also documented by zoned micas with cores of "lithian annite" and rims of zinnwaldite (Rub et al. 1983). Similar mica zoning was observed between lepidolite and zinnwaldite granites, where the inner zone of mica crystals is formed by zinnwaldite and the outer zone by lepidolite (Rub et al. 1998). Typical is also drop in fluorine concentrations, from c. $7.5 \mathrm{wt}$. \%

ppm

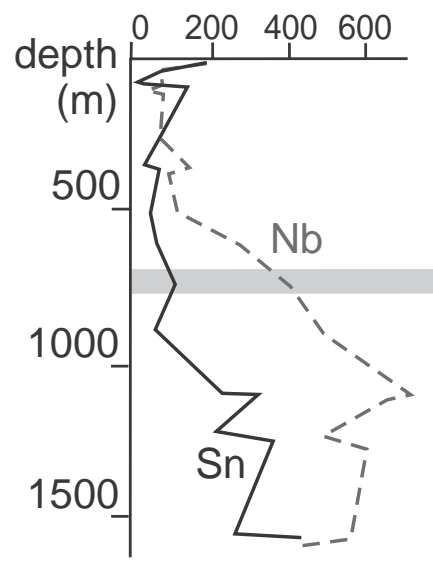

\section{mica transition zone}

Fig. 10 Distribution of $\mathrm{Sn}, \mathrm{W}, \mathrm{Nb}$ and $\mathrm{Ta}$ in $\mathrm{Li}-\mathrm{Fe}$ micas from the analyses of mica concentrates in Rub et al. (1983) and electron-microprobe analyses by Johan et al. (2012). 
Tab. $5 \mathrm{Li}-\mathrm{Fe}$ mica chemical composition of the porphyritic microgranite (pG) and mediumgrained granite $(\mathrm{mgG})$ determined by electron microprobe (in wt. \%)

\begin{tabular}{|c|c|c|c|c|c|c|}
\hline number & 1 & 2 & 3 & 4 & 5 & 6 \\
\hline texture & $\mathrm{pG}$ & $\mathrm{pG}$ & $\mathrm{mgG}$ & $\mathrm{mgG}$ & $\mathrm{mgG}$ & $\mathrm{mgG}$ \\
\hline $\mathrm{n}$ & 4 & 4 & 2 & 4 & 2 & 4 \\
\hline $\mathrm{SiO}_{2}$ & 39.05 & 39.84 & 40.42 & 39.89 & 40.07 & 40.49 \\
\hline $\mathrm{TiO}_{2}$ & 0.51 & 0.42 & 0.38 & 0.39 & 0.48 & 0.31 \\
\hline $\mathrm{Al}_{2} \mathrm{O}_{3}$ & 20.84 & 20.89 & 21.37 & 20.92 & 20.79 & 21.10 \\
\hline $\mathrm{FeO}$ & 19.45 & 17.61 & 17.38 & 18.29 & 17.9 & 17.33 \\
\hline $\mathrm{MnO}$ & 0.75 & 0.74 & 0.74 & 0.74 & 0.73 & 0.74 \\
\hline $\mathrm{MgO}$ & 0.14 & 0.13 & 0.13 & 0.15 & 0.12 & 0.14 \\
\hline $\mathrm{K}_{2} \mathrm{O}$ & 9.38 & 9.29 & 9.39 & 9.51 & 9.40 & 9.36 \\
\hline $\mathrm{Na}_{2} \mathrm{O}$ & 0.28 & 0.31 & 0.33 & 0.24 & 0.27 & 0.34 \\
\hline $\mathrm{Rb}_{2} \mathrm{O}^{*}$ & 1.26 & 1.32 & 1.40 & 1.32 & 1.32 & 1.39 \\
\hline $\mathrm{F}$ & 6.71 & 7.03 & 7.61 & 7.10 & 7.10 & 7.46 \\
\hline$-\mathrm{F}=\mathrm{O}$ & 2.82 & 2.95 & 3.15 & 2.98 & 2.98 & 3.13 \\
\hline $\mathrm{Li}_{2} \mathrm{O} * *$ & 1.63 & 1.86 & 2.03 & 1.88 & 1.93 & 2.05 \\
\hline $\mathrm{H}_{2} \mathrm{O} * * *$ & 0.70 & 0.56 & 0.35 & 0.55 & 0.55 & 0.41 \\
\hline Total & 97.88 & 97.05 & 98.38 & 98.00 & 97.65 & 97.99 \\
\hline Si apfu & 6.016 & 6.11 & 6.115 & 6.083 & 6.122 & 6.139 \\
\hline IV $\mathrm{Al}$ & 1.884 & 1.881 & 1.885 & 1.907 & 1.878 & 1.861 \\
\hline${ }^{\mathrm{VI}} \mathrm{Al}$ & 1.800 & 1.902 & 1.925 & 1.859 & 1.867 & 1.921 \\
\hline $\mathrm{Ti}$ & 0.059 & 0.049 & 0.043 & 0.045 & 0.055 & 0.035 \\
\hline $\mathrm{Fe}$ & 2.506 & 2.262 & 2.199 & 2.336 & 2.287 & 2.198 \\
\hline $\mathrm{Mn}$ & 0.098 & 0.096 & 0.095 & 0.096 & 0.094 & 0.095 \\
\hline $\mathrm{Mg}$ & 0.032 & 0.030 & 0.029 & 0.034 & 0.027 & 0.032 \\
\hline $\mathrm{Li}$ & 1.026 & 1163 & 1.246 & 1.165 & 1.197 & 1.262 \\
\hline $\mathrm{K}$ & 1.843 & 1.820 & 1.812 & 1.853 & 1.832 & 1.810 \\
\hline $\mathrm{Na}$ & 0.084 & 0.092 & 0.097 & 0.071 & 0.080 & 0.100 \\
\hline $\mathrm{Rb}$ & 0.125 & 0.130 & 0.136 & 0.130 & 0.130 & 0.135 \\
\hline $\mathrm{F}$ & 3.269 & 3.415 & 3.641 & 3.430 & 3.431 & 3.577 \\
\hline $\mathrm{OH}$ & 0.720 & 0.577 & 0.354 & 0.560 & 0.561 & 0.417 \\
\hline Total & 19.462 & 19.527 & 19.577 & 19.569 & 19.561 & 19.582 \\
\hline $\mathrm{Y}$ total & 5.520 & 5.501 & 5.538 & 5.535 & 5.528 & 5.542 \\
\hline $\mathrm{X}$ total & 2.053 & 2.043 & 2.045 & 2.053 & 2.042 & 2.046 \\
\hline Al total & 3.784 & 3.782 & 3.810 & 3.776 & 3.744 & 3.782 \\
\hline $\mathrm{Fe} /(\mathrm{Fe}+\mathrm{Mg})$ & 0.987 & 0.987 & 0.987 & 0.986 & 0.988 & 0.986 \\
\hline $\mathrm{Mn} /(\mathrm{Mn}+\mathrm{Fe})$ & 0.038 & 0.041 & 0.041 & 0.039 & 0.040 & 0.041 \\
\hline
\end{tabular}

* The $\mathrm{Rb}_{2} \mathrm{O}$ concentrations estimated from $\mathrm{F}$ concentrations in Rub et al. (1983) and Johan et al. (2012) using the regression line equation $\mathrm{Rb}_{2} \mathrm{O}=0.149+0.166 \mathrm{~F}$

** $\mathrm{Li}_{2} \mathrm{O}$ concentrations calculated after Tischendorf et al. (1997)

*** $\mathrm{H}_{2} \mathrm{O}$ amounts after Tindle and Webb (1990)

The biotite formula calculation has been carried out by the program of Tindle (2001)

varies between 60 and $100 \mathrm{ppm}$ and Cs between 400 and 600 ppm (Breiter et al. 2015b).

\subsection{Accessory and ore minerals}

The studied Cínovec granites are characterized by an absence of apatite or tourmaline, which are otherwise typical accessory minerals in granites of the Western Pluton of the KHEB (Lange et al. 1972). Topaz and fluorite are the main accessory minerals at Cínovec (Fig. 3) contributing, together with lithium micas, to the high $\mathrm{F}$ concentration in zinnwaldite granites (up to 0.75 wt. \%) and lithian annite granites (up to $\sim 0.5 \mathrm{wt}$ \%).

The amount of zircon is also relatively low if compared to biotite granites from elsewhere in the KHEB (Lange et al. 1972). Breiter and Škoda (2012) determined $\mathrm{ThO}_{2}$ concentrations in zircons of $1-5 \mathrm{wt}$. \% in the upper but only $0.5 \mathrm{wt}$. \% in the lower suite granites. The $\mathrm{Y}_{2} \mathrm{O}_{3}$ concentrations are elevated, mostly in the range of 0.3-5 wt. \%. High F concentrations were determined in zircons from the upper granites (Johan and Johan 2005). Uranium contents range mostly $0-2$ wt. $\% \mathrm{UO}_{2}$, but they may occasionally reach as much as 6 wt. \% (Breiter and Škoda 2012).

Apart from zircon, uranium in the granites is hosted by the REE minerals of the bastnäsite group. Thorite is abundant in lithian annite granites, where it is associated with zircon, preferentially included in $\mathrm{Li}-\mathrm{Fe}$ micas. Monazite is rare in zinnwaldite granites, but occurs abundantly in the

$\mathrm{F}$ in zinnwaldite to $c$. $3.5 \mathrm{wt}$ \% $\mathrm{F}$ in lithian annite. In lithian annite, $\mathrm{Rb}_{2} \mathrm{O}$ concentrations vary around 0.93 wt. \% (Štemprok and Šulcek 1969) and in zinnwaldite, from 0.92 to 1.20 wt. \% (Johan et al. 2012). Breiter et al. (2015a) found $\mathrm{Rb}_{2} \mathrm{O}$ concentrations $0.5 \mathrm{wt} . \%$ in lithian annite and 1.7 wt. \% in zinnwaldite.

The trace-element composition (Fig. 10) is marked by a significant increase of $\mathrm{Sn}, \mathrm{Nb}$ and Ta in lithian annite if compared with zinnwaldite (Rub et al. 1983; Johan et al. 2012). In contrast, $W$ concentrations are about the same in both mica types (Fig. 10). The new data for trioctahedral micas of the upper and lower suites indicate that Sc lower suite granites, which are Th enriched (Cocherie et al. 1991; Johan and Johan 2005). Yttrium is predominantly hosted by xenotime (Breiter and Škoda 2012), common in lithian annite granites but practically absent in zinnwaldite granites (Johan and Johan 2005).

The ore mineralization is represented by cassiterite and wolframite, with minor scheelite in ore veins and greisens. Tin concentrations are associated with cassiterite, which occurs in two different rock suites: in greisens and quartz veins. It forms dark brown grains (up to 0.2 $\mathrm{mm}$ ) and, more often, light brown grains (up to $\sim 0.3$ $\mathrm{mm})$. Tungsten is hosted in wolframite and scheelite, 
Fig. 11 Distribution of the $\mathrm{SiO}_{2}, \mathrm{Al}_{2} \mathrm{O}_{3}$, $\mathrm{Fe}_{2} \mathrm{O}_{3}$ and $\mathrm{CaO}$ concentrations with depth from published and new silicate analyses. The legend of the geological profile as in Fig. 2.

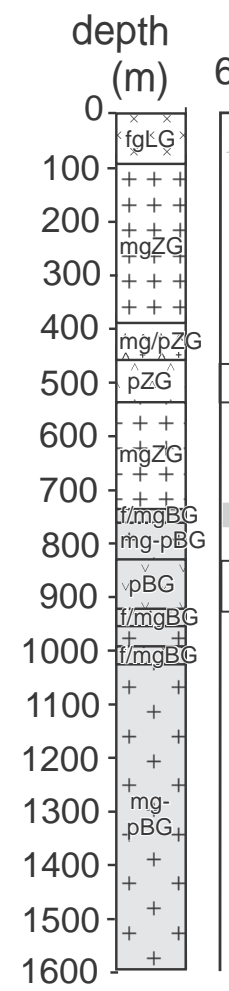

wt. $\%$
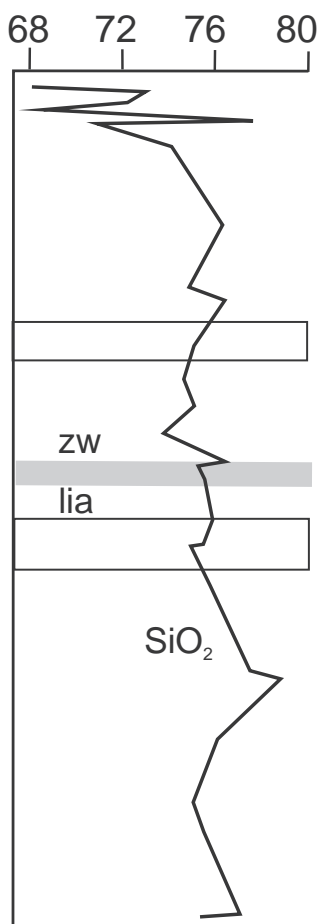

$5 \quad$ wt. $\%$
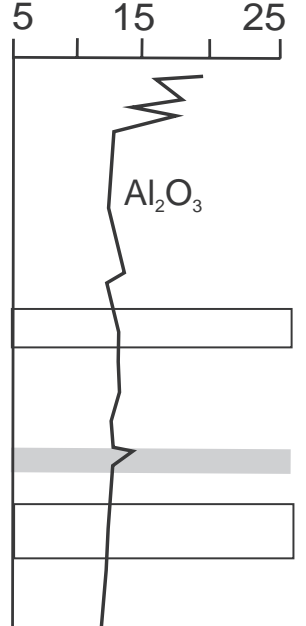

mica transition zone wt. $\%$

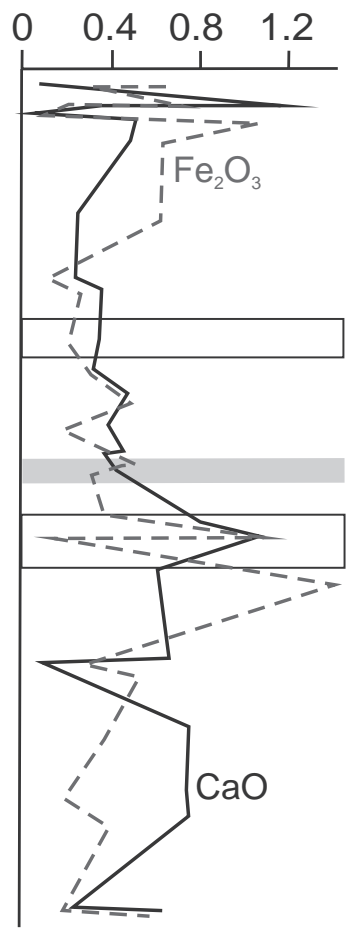

microgranites

wt. \%

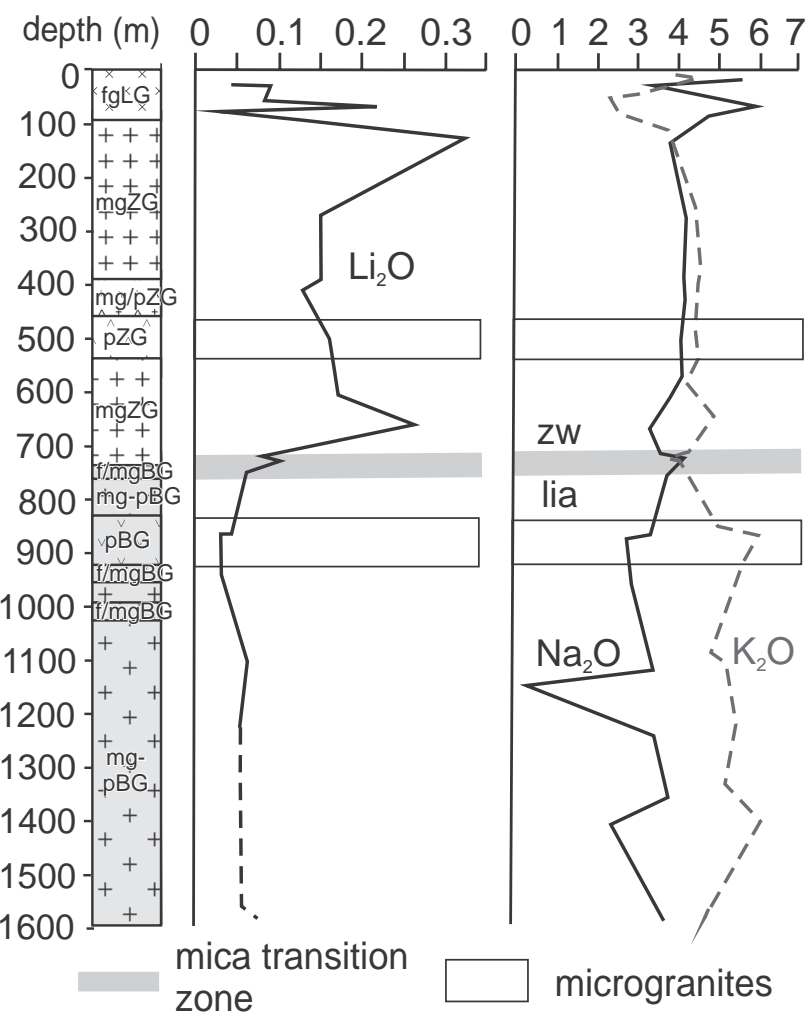

Fig. 12 Distribution of $\mathrm{Li}_{2} \mathrm{O}, \mathrm{Na}_{2} \mathrm{O}$ and $\mathrm{K}_{2} \mathrm{O}$ concentrations with depth from published and new silicate analyses. The legend of the geological profile as in Fig. 2. 
mostly from 0.2 to 0.6 wt. \%, but may exceed 1 wt. \% in zones of hydrothermal alteration. $\mathrm{CaO}$ abundances (Fig. 11) vary c. $0.2-0.4 \mathrm{wt} . \%$ in the upper granites, but are continuously increased to $c$. $0.7 \mathrm{wt}$. \% in the lower granites. The peaks on the curve reflect the presence of fluorite mineralization in fissures (Štemprok 1965). The lithium curve (Fig. 12) shows peaks in zones of greisenization, in lepidolite and zinnwaldite granites, where $\mathrm{Li}_{2} \mathrm{O}$ concentrations are increased to $c .0 .3$ wt. \%. Zinnwaldite granites contain c. 0.15 wt. $\% \mathrm{Li}_{2} \mathrm{O}$ and lithian annite granites c. 0.05 wt. $\% \mathrm{Li}_{2} \mathrm{O}$. The $\mathrm{Li}_{2} \mathrm{O}$ peak at a depth of $650 \mathrm{~m}$ coincides with a zone of strong phyllic alteration. The increased $\mathrm{Na}_{2} \mathrm{O}$ concentrations in lepidolite granites (up to 6 wt. \%; Fig. 12), mirror an increased albite amount. Zinnwaldite granites have the maximum $\mathrm{Na}_{2} \mathrm{O}$ concentrations at c. 4.0 wt. $\% ; \mathrm{Na}_{2} \mathrm{O}$ in the lower granites is variable but mostly $\sim 3.8 \mathrm{wt}$. \%. Sodium is depleted in zones of sericitization and the presence of this alteration in all the granite varieties explains the irregular shape of the $\mathrm{Na}_{2} \mathrm{O}$ curve (Štemprok and Šulcek 1969; this study). The curve of $\mathrm{K}_{2} \mathrm{O}$ contents shows a typical depletion in the albite-rich zone of the lepidolite granite, to $c .2 \mathrm{wt} \%$.
In the upper granites, $\mathrm{K}_{2} \mathrm{O}$ varies around $4.0 \mathrm{wt}$. $\%$ and in the lower granites it reaches 5 wt. \% (Fig. 12).

There is no correlation of $\mathrm{Na}_{2} \mathrm{O}$ or $\mathrm{K}_{2} \mathrm{O}$ with $\mathrm{Li}_{2} \mathrm{O}$ (Fig. 13); a weak negative correlation exists between $\mathrm{Na}_{2} \mathrm{O}$ and $\mathrm{CaO}$, which can be explained by albitization of plagioclase, the main calcium host. Negative correlation between $\mathrm{K}_{2} \mathrm{O}$ and $\mathrm{Na}_{2} \mathrm{O}$ suggests that many of changes in major-element compositions occurred between albite and $\mathrm{K}$-feldspar, presumably in course of variable alteration (alkali exchange reactions and phyllic alterations; Fig. 13). The $\mathrm{P}_{2} \mathrm{O}_{5}$ concentrations in all the granites are very low, mostly from 0.01 to $0.06 \mathrm{wt}$. \%. Fluorine concentrations in the upper granites have an average of $0.7 \mathrm{wt}$. \%, and in the lower granites $\sim 0.4$ wt. \% F (Rub et al. 1983).

\section{2. $\mathrm{Fe}_{\mathrm{tot}^{\prime}} \mathrm{Ti}$, and trace elements}

The distributions of $\mathrm{Fe}_{\text {tot }}$ and Ti from XRF analyses indicate a notable increase in $\mathrm{Fe}$ and $\mathrm{Ti}$, from the upper to the lower granite suite (Fig. 14). The $\mathrm{Rb}$ abundances reach maximum in the upper granites (up to $0.3 \mathrm{wt}$.) but are systematically lowered in lithian annite granites, down to
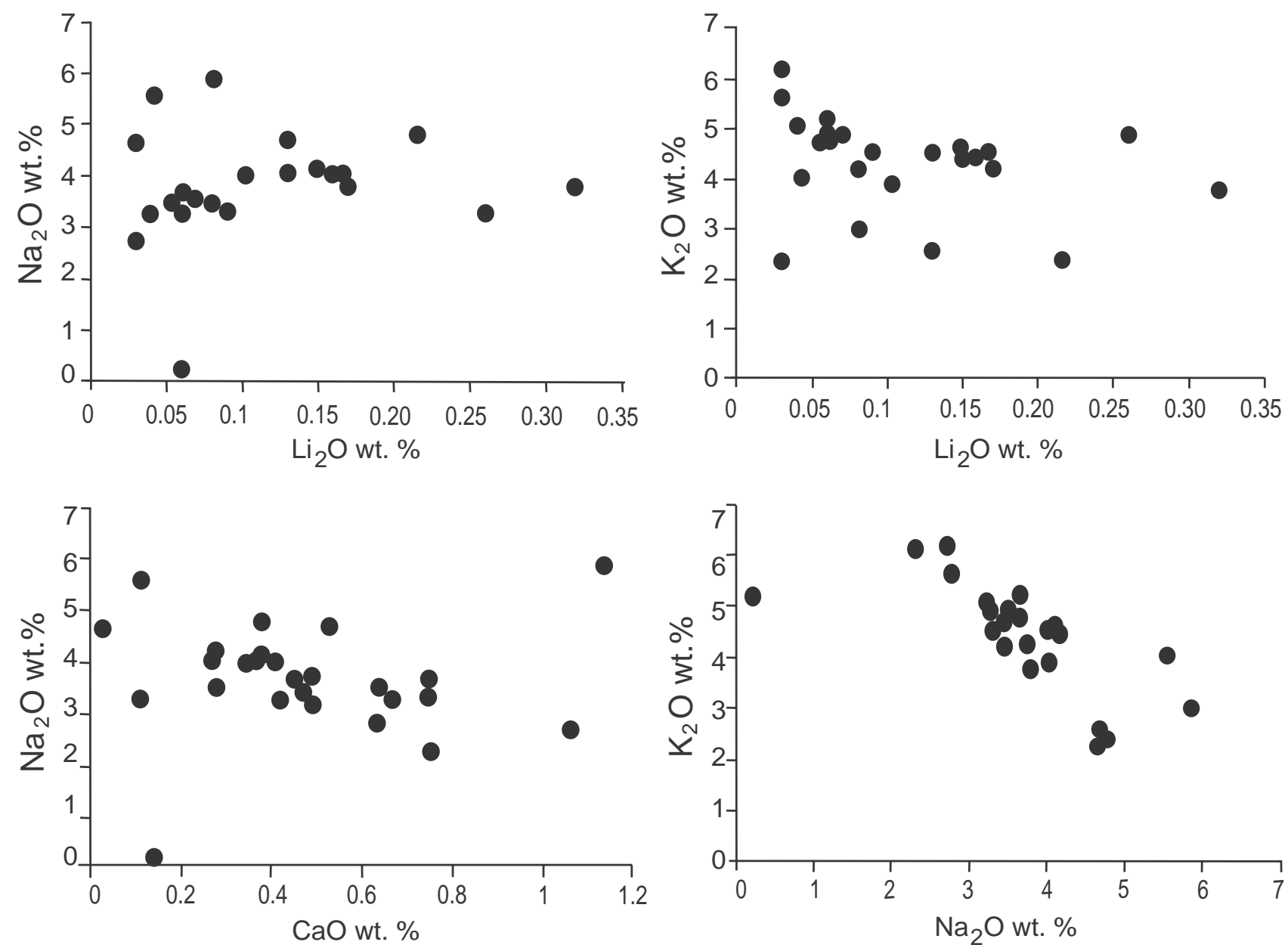

Fig. 13 Variation diagrams of $\mathrm{K}_{2} \mathrm{O}, \mathrm{Na}_{2} \mathrm{O}, \mathrm{Li}_{2} \mathrm{O}$ and $\mathrm{CaO}$ based on silicate analyses from the granites of the CS-1 drill core. 
Fig. 14 Distribution of $\mathrm{Fe}$, Ti and $\mathrm{Ba}$ with depth in the drill core CS-1 based on XRF analyses. The legend of the geological profile as in Fig. 2.

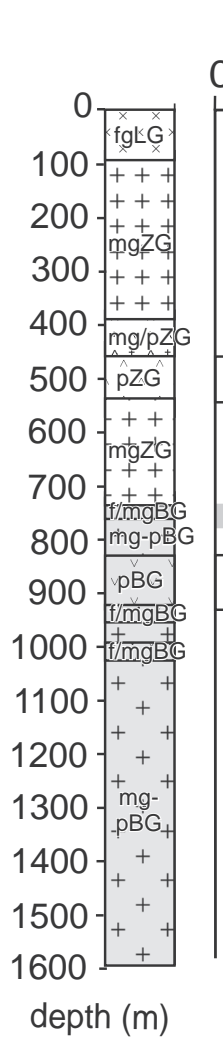

wt. $\%$
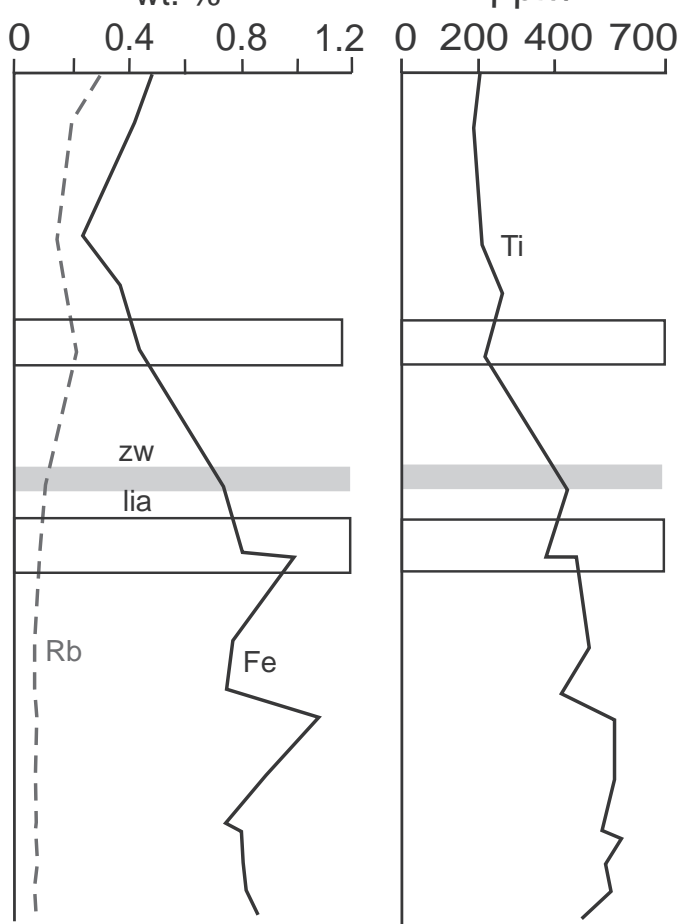

mica transition zone ppm

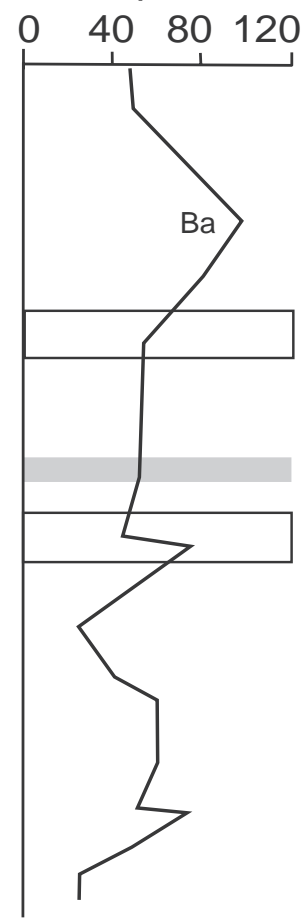

microgranites c. 0.07 wt. \% (Štemprok and Šulcek 1969). There is also a weak decrease in Ba concentrations from the upper to the lower granite suites.

Niobium concentrations determined by XRF vary around $50 \mathrm{ppm}$, with an increase to $80 \mathrm{ppm}$ below the ore zone at $310 \mathrm{~m}$ (Fig. 15). According to new analyses (Breiter et al. 2015b), Nb concentrations differ systematically between the upper (c. 80-100 ppm) and lower granite suites (c. $50 \mathrm{ppm}$ ) and are raised in the upmost granites to c. $150 \mathrm{ppm}$. Tantalum concentrations are slightly increased in zinnwaldite granites ( $\sim 0 \mathrm{ppm}$ ), but in the uppermost lepidolite granites they may reach $212 \mathrm{ppm}$ (Rub et al. 1998). Zirconium is generally low in the whole profile (Fig. 15). In the uppermost granites, to a depth of $300 \mathrm{~m}$, Zr concentrations are $\sim 80 \mathrm{ppm}$ and they progressively rise from there. Lithian annite granites contain c. 100 ppm Zr. Yttrium curve shows a trend parallel to $\mathrm{Zr}$, with lower Y concentrations (c. $80 \mathrm{ppm}$ ) in the depth range of 100-300 $\mathrm{m}$. From there downwards, the Y concentrations increase to $120-140 \mathrm{ppm}$ in the lower suite granites.

Tungsten concentrations in the CS- 1 drill core are 0.11 wt. $\%$ in the flat vein zone, and 0.12 wt. $\%$ in a zone of strong argillitic alteration with quartz veinlets at a depth of 835-840 m (Štemprok and Šulcek 1969). The curve of W concentrations in Fig. 16 shows a minor elevation to $\sim 25$ ppm in the upper granite suite and systematic decrease in the lower suite granites. The curve of Mo shows practically no difference between the upper and the lower granite suites with a single peak around $1200 \mathrm{~m}$ depth, where minor greisen mineralization was observed (Štemprok 1964). Increased amounts of $\mathrm{Bi}$ and $\mathrm{As}$ in the upper suite granites are well documented by the corresponding distribution curves with a maximum in the greisenization zone (Fig. 16).

The analyses of 169 samples show a distinct association of elevated Sn concentrations (in in order of several hundreds of ppm; Fig. 17) with greisens and ore veins at the top of the cupola, down to a depth of $167 \mathrm{~m}$ (Electronic Supplementary Material 1). Deeper, the Sn concentrations of $100 \mathrm{ppm}$ are exceeded in narrow core sections at 250-260 m and 308-309 m depth. Noteworthy are increased Sn concentrations at 610-670 m, i.e. near the bottom of the upper suite. In the lower suite granites, increased Sn concentrations at c. $900 \mathrm{~m}$ depth coincide with zones of argillic alteration (Štemprok and Šulcek 1969), and at 1210-1220 m (120 ppm) and 1250-1260 $\mathrm{m}(90 \mathrm{ppm})$ in the vicinity of thin zones of minor greisenization accompanied by sulphide mineralization (Štemprok 1964). All these values may indicate the effect of greisenization and phyllic alteration in the Cínovec granites, caused by epigenetic hydrothermal processes rather than reflecting changes in primary concentration of Sn-bearing minerals from a magmatic stage.

The beryllium contents are slightly variable in the upper granites (4-20 ppm; Fig. 17). In the lower granites Be distribution is relatively irregular with several peaks exceeding $60 \mathrm{ppm}$ and with a single maximum of $180 \mathrm{ppm}$ 


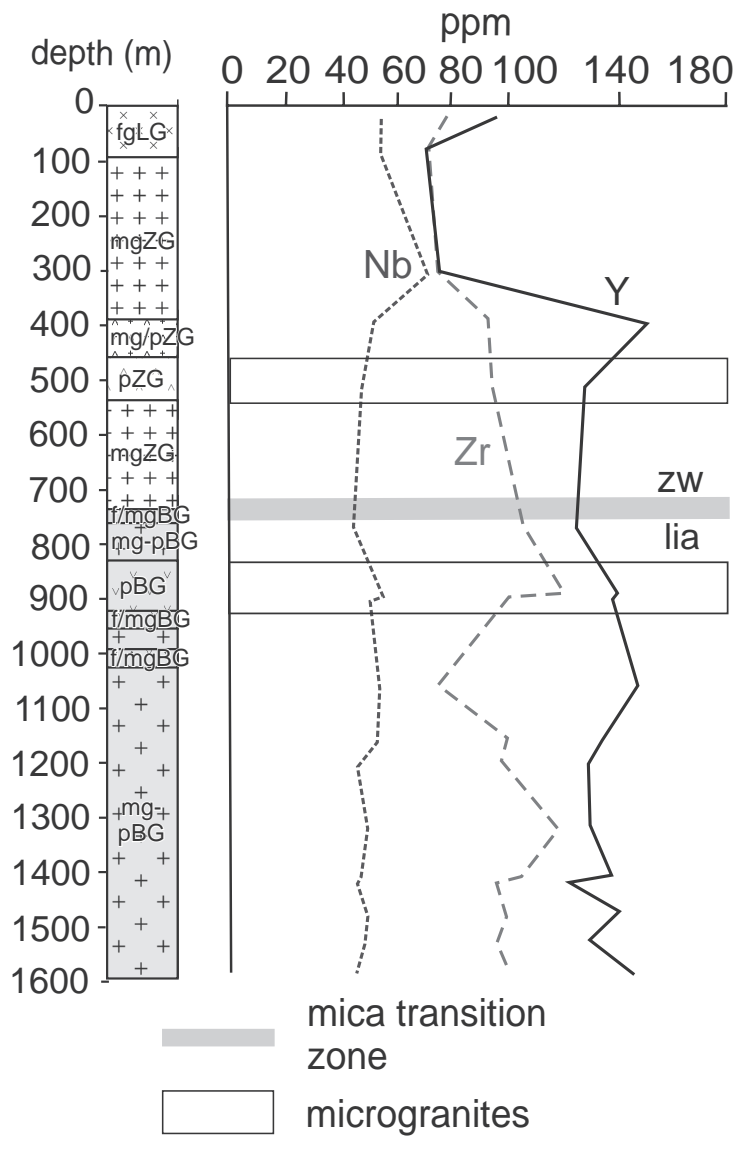

Fig. 15 Distribution of $\mathrm{Nb}, \mathrm{Zr}$ and $\mathrm{Y}$ with depth in the drill core $\mathrm{CS}-1$ based on XRF analyses. The legend of the geological profile as in Fig. 2.

at a depth of $740-750 \mathrm{~m}$. The latter peak suggests a possible heterogeneous admixture of a Be-bearing phase not yet identified. The granites examined in the CS-1 drill core differ from some apogranites in Transbaikalian regions described by Beus et al. (1962), enriched in beryllium.

The results of gamma-ray spectrometric analyses of $\mathrm{U}$ and $\mathrm{Th}$ are shown in Fig. 18. Uranium concentrations vary from 5 to $55 \mathrm{ppm}$; increased concentrations are mainly below a $400 \mathrm{~m}$ depth with narrow peaks considered to be related to fractured granites. The same element determined by XRF shows a similar concentration range of $12-41 \mathrm{ppm}$ with no preference for a particular petrographic unit (Tab. 1). Chlupáčová (2015) gave different averaged U concentrations, 15.5 ppm in strongly altered and greisenized albite granites and $22.0 \mathrm{ppm}$ in medium- and coarse-grained albite granites. Thorium concentrations are systematically increased from $\sim 20 \mathrm{ppm}$ in upper zinnwaldite granites to $c$. $70 \mathrm{ppm}$ in lithian annite granites. The data are slightly higher than the average value of 49.9 ppm $(\mathrm{n}=49)$ determined in lithian annite granites by Chlupáčová (2015). Hence the Th/U ratio varies between 0.3 and 5.7, with no distinct control by the textural variants of granites (Fig. 18).

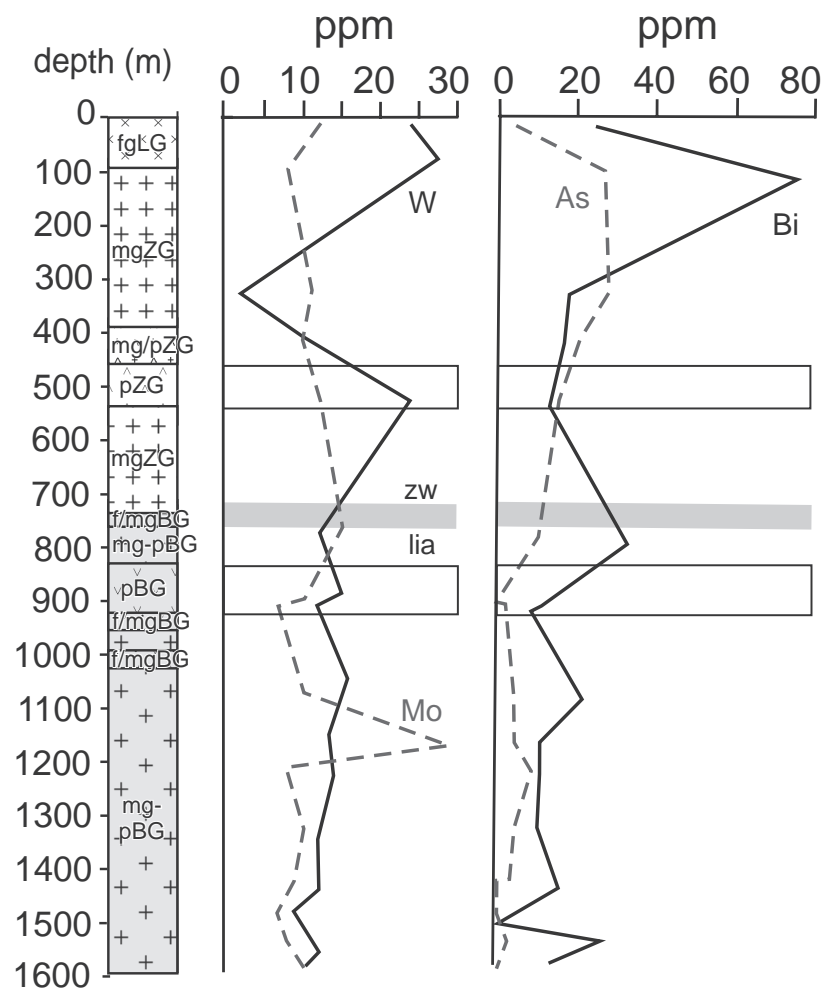

\section{mica transition zone}

microgranites

Fig. 16 Distribution of W, Mo, Bi and As with depth in the drill core CS-1 based on XRF analyses. The legend of the geological profile as in Fig. 2.

Both granite suites give rather flat chondrite-normalized patterns with deep negative Eu anomalies $\left(0.002<\mathrm{Eu} / \mathrm{Eu}^{*}<0.03\right)$ (Štemprok 1989; Cocherie et al. 1991) and substantial tetrad effect (Dolejš and Štemprok 2001). In the lower suite granites, total REE concentrations remain relatively constant at $\sim 220 \mathrm{ppm}$ whereas in the upper suite granites they decrease to 30-60 ppm (Štemprok 1989; Cocherie et al. 1991). The chemical data show a major decrease in the amount of elements associated with zircon and monazite (e.g. Zr, $\mathrm{Y}, \mathrm{REE}$ and $\mathrm{Th}$ ) above the $\sim 400 \mathrm{~m}$ depth (Dolejš and Štemprok 2001). This boundary may be linked with the dissolution of accessory minerals by circulating shallow hydrothermal fluids, but does not coincide with the boundary between the zinnwaldite and lithian annite granites based on mica compositions.

\section{Geochemical differences between the textural variants in the CS-1 drill core}

\subsection{Variation of compositional curves}

Two continuous microgranite zones - one in the upper granite suite and the other in the lower suite - are 


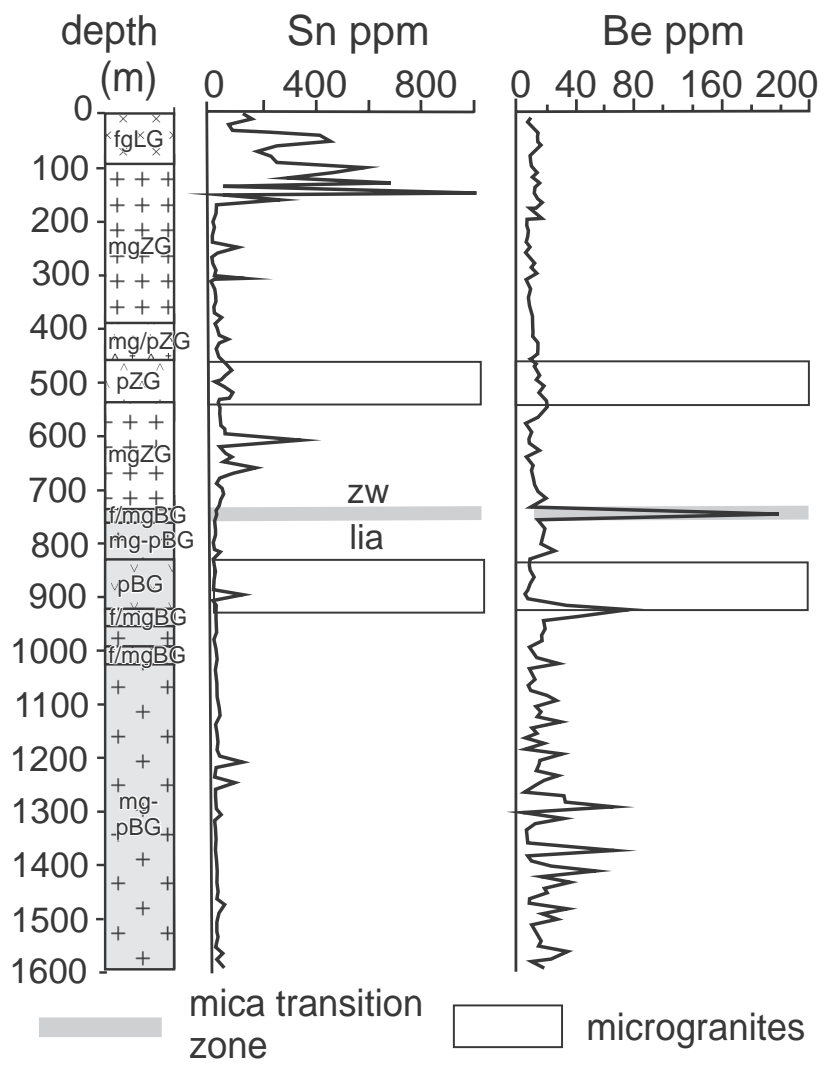

Fig. 17 Distribution of Sn and Be with depth in the drill core CS-1 from optical spectroscopy analyses. The legend of the geological profile as in Fig. 2.

surrounded by zones of interchange between mediumgrained and microgranite variants. The well logs (Figs 11-12) highlight the microgranite variants and their effect on the course of the compositional curves. It is negligible in upper granite suite suggesting a similar effect of postmagmatic hydrothermal overprint on the original granite lithology. The curves show notable changes in $\mathrm{CaO}$ and $\mathrm{Fe}_{2} \mathrm{O}_{3}$ over the lower microgranite body, suggesting the effect of dispersed hematite, fluorite and calcite, also observed as filling fractures in the microgranite (Fig. 11). The peaks on the Ba curve may reflect the presence of barite as a common associate of fluorite in some fracture fillings (Fig. 14).

\subsection{Geochemical differences between textural varieties}

Geochemical differences between the textural varieties in the mica transition zone are presented in Tabs 3-4. The major-element analyses show decrease in $\mathrm{SiO}_{2}$ from 76.46 wt. $\%$ in microgranite to 75.32 wt. \% in mediumgrained granite. The $\mathrm{Al}_{2} \mathrm{O}_{3}$ concentration increases from 12.98 wt. \% in microgranite to 14.16 wt. \% in mediumgrained granite. Alkalies show opposite trends; $\mathrm{Na}_{2} \mathrm{O}$ increases from 3.46 to $4.03 \mathrm{wt}$. \%, whereas $\mathrm{K}_{2} \mathrm{O}$ decreases

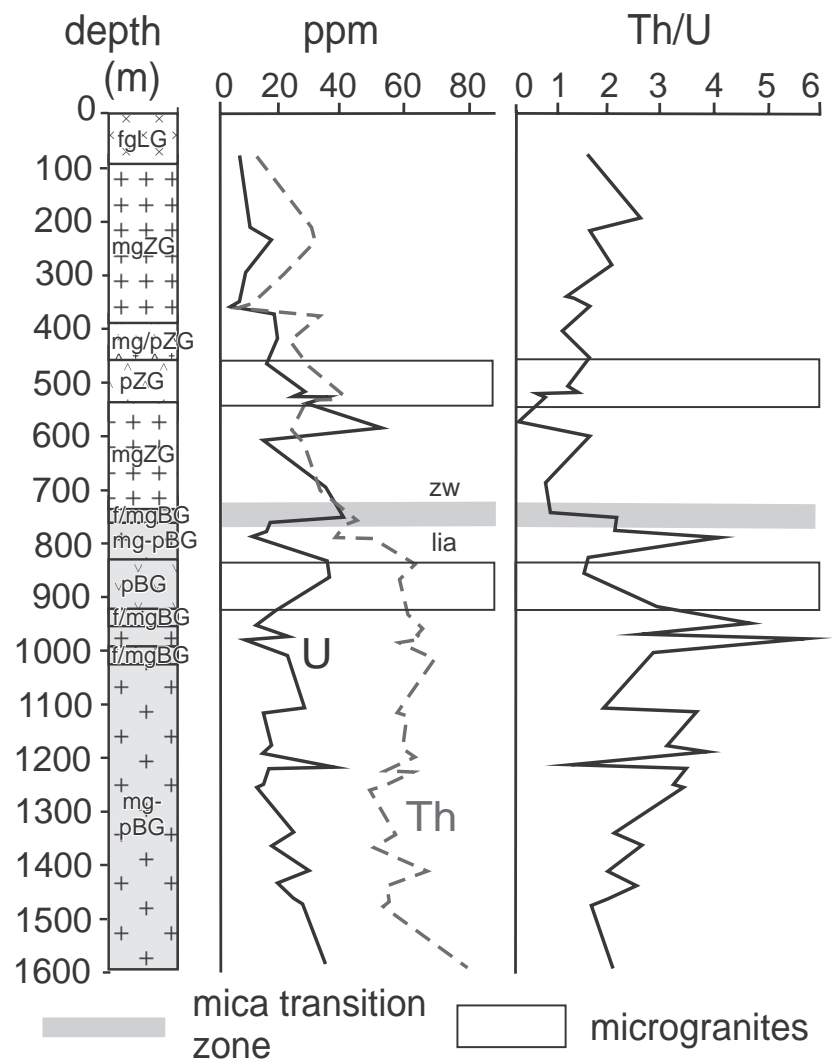

Fig. 18 Distribution of $U, T h, U$ eq. and of $T h / U$ with depth in the drill core CS-1 based on radiometric analyses. The legend of the geological profile as in Fig. 2.

from $4.20 \mathrm{w} \%$ to $3.89 \mathrm{wt} \%$. The $\mathrm{Li}_{2} \mathrm{O}$ concentration in microgranite is 0.08 wt. \% (Tab. 4) and it is enriched compared to the average lithian annite granite $(\sim 0.05$ wt. $\left.\% \mathrm{Li}_{2} \mathrm{O}\right)$. The medium-grained granite has $\mathrm{Li}_{2} \mathrm{O}$ contents of $0.10 \mathrm{wt}$. \%, i.e. lower than most of zinnwaldite granites (average 0.15 wt. \%). Rubidium concentrations decrease from $1194 \mathrm{ppm}$ in microgranite to $1093 \mathrm{ppm}$ in medium-grained granite. Despite a remarkable change in the $\mathrm{Na}_{2} \mathrm{O}$ contents between both granite variants, the $\mathrm{CaO}$ concentrations are relatively stable (from 0.47 to 0.41 wt. \%) similarly to F concentrations which are $~ 0.6$ wt. \% in both granite types.

The elements associated with accessory minerals (such as $\mathrm{Zr}, \mathrm{Y}, \mathrm{Th}$ ) are constantly slightly enriched in microgranite compared to the medium-grained granite, $\mathrm{U}$ is increased to $\sim 60 \mathrm{ppm}$ in medium-grained granite from $\sim 30 \mathrm{ppm}$ in microgranite. Niobium and Ta concentrations are not significantly changed $(\mathrm{Nb} 68.6 / 88.2 \mathrm{ppm}$ and $\mathrm{Ta}$ 7.7/11.0 ppm). The $\mathrm{Rb} / \mathrm{Sr}$ ratio is very high in both granite variants: 205.5 in microgranite and 291.4 in medium-grained granite. Both rocks contain high modal quartz and whole-rock $\mathrm{SiO}_{2}$ concentrations and are therefore likely to be least affected by local differences in accessory-phase distribution. Thus, the linear isocon diagram (Fig. 19) with Si-immobile isocon (approximate- 


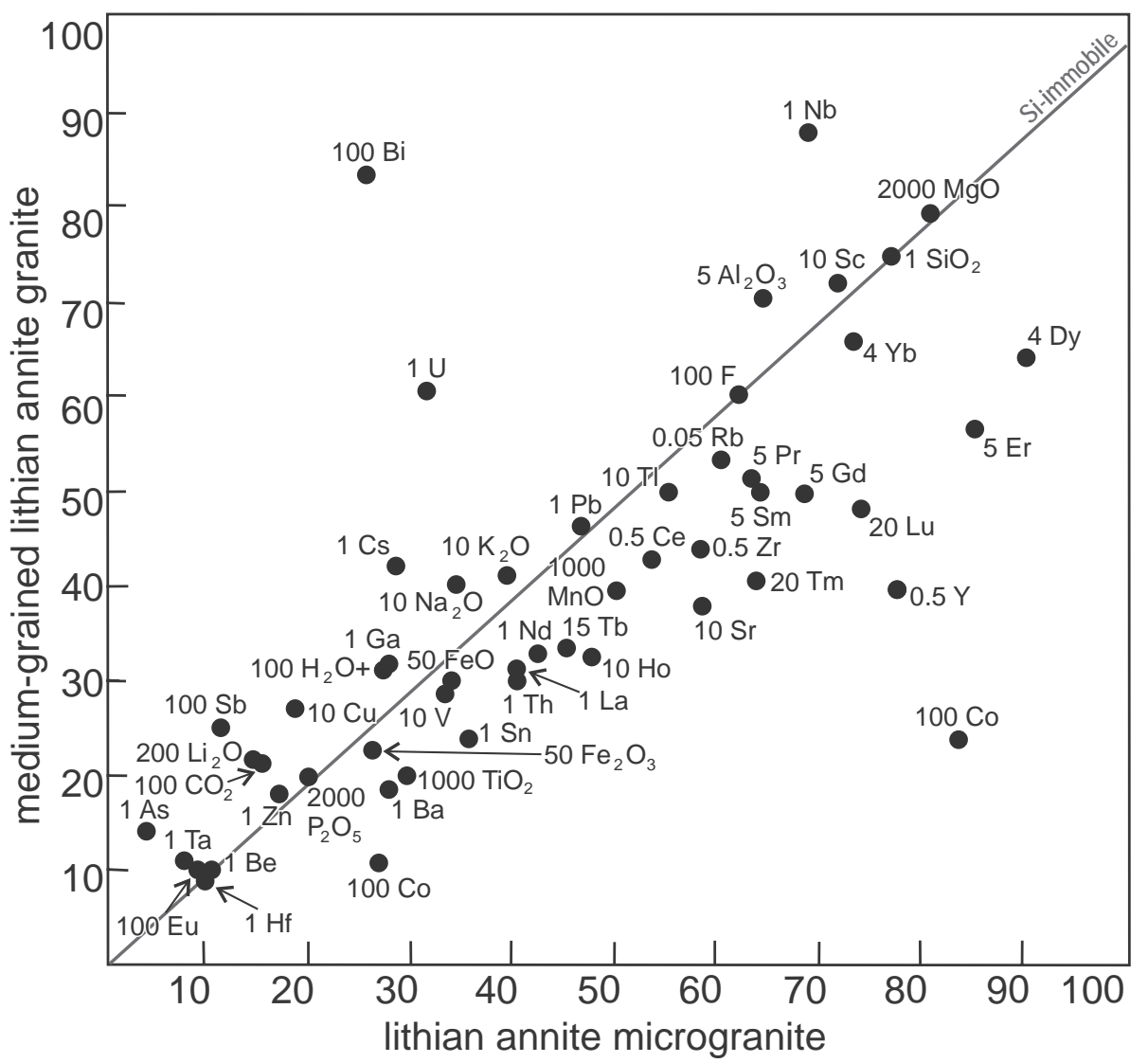

Fig. 19 Isocon diagram for microgranite and medium-grained lithian annite granite from a $724.6-8 \mathrm{~m}$ depth. Units correspond to wt. \% (major elements) and to ppm (trace elements) multiplied by factors indicated in individual labels. ly 1) is used to quantify these data in a graphical form as previously proposed by Dolejš and Štemprok (2001).

The normalized REE patterns are flat and show deep Eu anomalies (Fig. 20). The curves for both granites have a parallel course but the microgranite is slightly enriched in REE compared to the medium-grained granite. The two new REE curves plot close to the field of lithian annite (protolithionite) granites but significantly

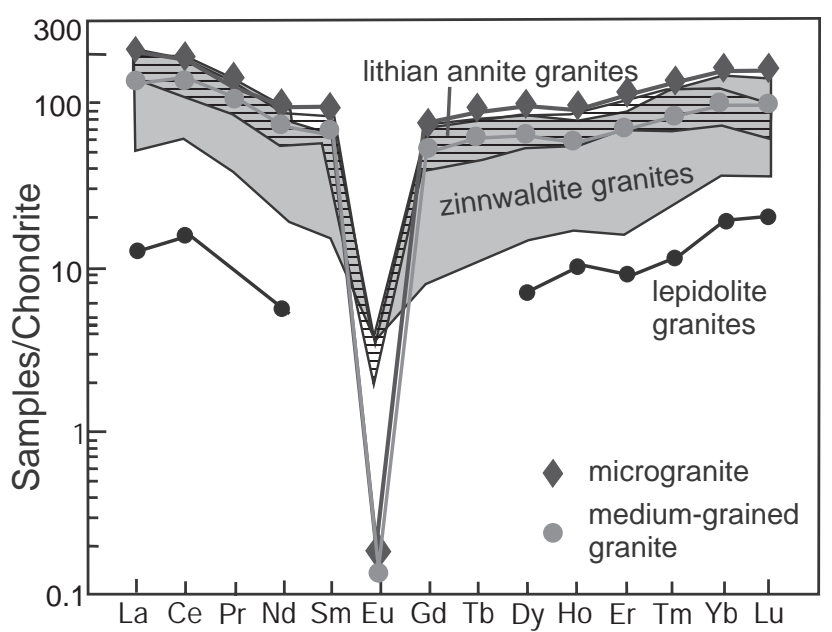

Fig. 20 Chondrite-normalized REE abundances of lithian annite microgranite and medium-grained lithian annite granites from a 724.6-8 m depth. Normalizing values from Sun and McDonough (1989). above that of the zinnwaldite granites recorded in the literature (Štemprok 1989; Dolejš and Štemprok 2001). The earlier data of lepidolite granites are characterized by the lowest $\Sigma$ REE. Figure 20 shows the symmetrical tetrad effect with a vertical line of Gd serving as the axis of symmetry. It has been documented as a general feature of rare-metal granites by Zhao et al. (1993). Data by Cocherie et al. (1991) and Monecke et al. (2007) revealed at least two tetrads in normalized whole-rock REE patterns of the Cínovec/Zinnwald granites, which document the participation of hydrothermal solutions in the granite origin.

\section{Discussion}

\subsection{Regional position}

The Cínovec/Zinnwald granite cupola is part of a composite volcano-plutonic unit termed the Eastern Volcano-Plutonic Complex (EVPC). It is spatially associated with $\mathrm{Sn}-\mathrm{W}$ mineralization in, or in the vicinity of, the YIC granites (such as Sadisdorf, Altenberg, Hegelshöhe, Schenckenshöhe, Preiselberk, and Knötl). The Cínovec-Krupka Pluton is located south of the outcropping Schellerhau (YIC) granite massif in Saxony (Fig. 1). The pluton remains hidden in its predominant 
part, but its upper surface between Cínovec and Krupka has been revealed by numerous drillings at Cínovec/ Zinnwald, Loupežný, Preiselberk and Knötl (Štemprok et al. 1994). The Li-F granites are always the youngest granitic rocks in this plutonic complex and are directly in contact with the country rock (e.g., at Cínovec/ Zinnwald or Knötl) but they can be emplaced into marginal earlier biotite granites, classified as the earliest members of the YIC (Altenberg, Preiselberk; Štemprok et al. 1994). In granite cusps, albite-rich granites are often rimmed at the top by a pegmatitic body (called in German Stockscheider). The multiphase nature of the granite cupolas was first recognized as early as in 1950 's, reflecting the concept of the so-called outer and inner granites (Oelsner 1952). In Altenberg, a body of albite granite, $c .100 \mathrm{~m}$ wide, is located below the ore zone inside the granite cupola and it is rimmed on the top by a pycnite-rich greisen, considered as a gresenized stockscheider (Hösel et al. 1997).

\subsection{Possible crustal and mantle sources}

The Variscan magmatic activity in the Eastern Krušné hory/Erzgebirge started at around 327-324 Ma (Dolejš et al. 2016) and it was followed by the emplacement of a porphyritic microgranite at $319 \pm 2 \mathrm{Ma}$ intersecting the Teplice rhyolite (Písečný vrch: Romer et al. 2010a). This represents an upper age limit for the intrusion of the YIC granites.

Neoproterozoic and Lower Paleozoic metaigneous and metasedimentary units of the Saxothuringian Domain are the potential sources of the Krušné hory/Erzgebirge Batholith. The classification of the Cínovec granites as $\mathrm{Li}-\mathrm{F}$ granites of the low- $\mathrm{P}_{2} \mathrm{O}_{5}$ subtype $(<0.1$ wt. \% $\mathrm{P}_{2} \mathrm{O}_{5}, \mathrm{Al}_{2} \mathrm{O}_{3}<14.5$ wt. \% and $\mathrm{SiO}_{2}>73$ wt. \%) points to a metaigneous protolith (Taylor and Fallick 1997). Variable $\mathrm{P}_{2} \mathrm{O}_{5}$ contents of the Eastern Krušné hory/ Erzgebirge microgranites may be indicative whether all the granitic pulses were derived from the same source. The marginal biotite microgranite was observed in the upper contact zone of the Krupka (Preiselberk) granite cupola (Štemprok et al. 2003; Fig. 1). It differs in $\mathrm{P}_{2} \mathrm{O}_{5}$ and $\mathrm{TiO}_{2}$ concentrations $(0.26-0.33$ and $0.19-0.24 \mathrm{wt}$. \%, respectively) from the enclosing medium-grained porphyritic biotite granite $\left(0.03-0.09\right.$ wt. $\% \mathrm{P}_{2} \mathrm{O}_{5}$ and $0.09-0.12$ wt. $\% \mathrm{TiO}_{2}$ ). This indicates that the YIC granite intrusions in the EVPC, such as Cínovec/Zinnwald and Krupka (Preiselberk), may have had contrasting sources, even varying between metaigneous and metasedimentary lithologies on a local scale.

Based on the evidence provided by lamprophyres with rare-metal mineralization that occur in the district, Seifert (2009) with Štemprok and Seifert (2011) proposed that there was a mantle component contributing to the granitic magmatism. The Late Variscan lamprophyre dykes preceded the YIC granites in the Krupka district (Śtemprok et al. 2014) and early members of the lamprophyre suite are greisenized in the districts with Sn-W mineralization. This resembles the situation in the Transbaikalian granite districts, where Li-F granites coincided spatially and temporally with lamprophyre and dolerite injections, bearing a witness of the mantle contribution to the granitic magmatism, substantiated also by isotopic data (Syritso 2002; Abushkevich and Syritso 2007). A possible upper mantle signature in the Cínovec granites was demonstrated by Dolejš and Štemprok (2001), who showed that the bulk $\delta^{18} \mathrm{O}_{\mathrm{wR}}$ values of the uppermost zinnwaldite and lepidolite granites are very low (5.2-5.8 \% SMOW) and thus marginally overlap with the average mantle values of $\sim 5.7 \%$ SMOW (Hoefs 1997). In contrast, mantle contribution was considered negligible by Breiter (2012) and metaluminous to slightly peraluminous A-type granites were interpreted as a product of low-degree melting of quartz-feldspathic rocks.

\subsection{Microgranites in YIC granites}

Microgranites or fine-grained porphyritic granites have been recognized in the deeply eroded Western Pluton of the KHEB as marginal bodies occurring in the apical parts of the YIC granite intrusions (Škvor 1974). Some of these microgranites were named as "Zwischengranite" and assigned to the earliest members of the YIC (Lange et al. 1972). Their textures were examined in detail in the Karlovy Vary Pluton near Doubí (Štemprok et al. 2008). Microscopic studies by many investigators confirmed the microgranites (granite porphyries) stage in the YIC granites of the Western Pluton, preserved in the groundmass (Fiala 1968). Seltmann and Štemprok (1994) reported two-phase textures in the microgranites of the YIC granites in the EVPC (such as Sadisdorf, Cínovec/ Zinnwald and Preiselberk).

The two-phase granitic textures were originally described from the South East Asian tin belt of Malaysia. They represent transitions from porphyritic granites, with a high proportion of phenocrysts, and thin films of equigranular aplitic matrix evolving towards sparsely porphyritic granites. These latter show a clear spatial separation of phenocrysts and their fragments and a high proportion of invasive equigranular matrix (Cobbing et al. 1992). The two-phase granites in the Karlovy Vary Pluton (Štemprok et al. 2008) are interpreted to represent products of rapid decompression, devolatilization and thermal disequilibrium crystallization in a closed system. This agrees with the interpretation that apical parts of intrusive bodies are potential sites of rapid, and often abrupt, cooling due to devolatilization and/or external fluid percolation and have frequently produced character- 


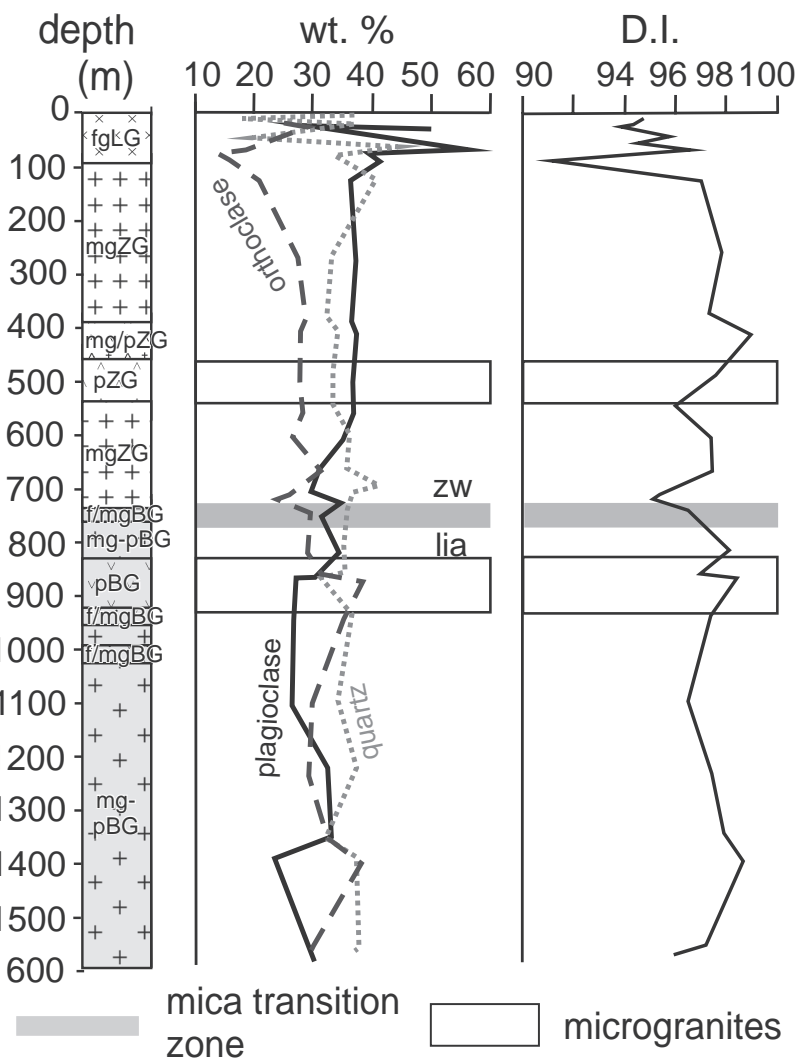

Fig. 21 The changes of the CIPW-normative mineral composition with depth based on silicate analyses from the granites of the CS-1 drill core. (D.I = differentiation index, the sum of normative quartz, plagioclase and orthoclase). The legend of the geological profile as in Fig. 2.

istic disequilibrium textures such as marginal pegmatitic, or quench carapaces.

\subsection{Changes in modal and normative composition with depth}

Cínovec granites exposed by the borehole CS-1 are characterized by a quartz/feldspar ratio ranging from 0.3 to 1.2 , which reflects both magmatic and postmagmatic processes (Fig. 2). The amount of quartz is typically lowered in albitites and K-feldspar-enriched rocks (metasomatic syenites) found in the Cínovec mine (Štemprok 1965).

The modal compositions do not show any significant depth-related variations between the medium- and finegrained variants (Fig. 2). Higher modal albite (30-35 vol. \%) in the upper zinnwaldite granites is explained by pervasive albitization that also increases the amount of albite in lepidolite granites. The K-feldspar content is relatively constant, in accord with a restricted range of $\mathrm{K}_{2} \mathrm{O}$ in the whole profile. Zinnwaldite and lithian annite are also homogenously distributed over the vertical profile, except for the mica-low zone and the uppermost, greisenized granites.
The CIPW-normative compositions (Hollocher 2016; Fig. 21) show a relatively stable amount of normative quartz (around 35 wt. \%) in the whole drill core. Normative plagioclase $(\mathrm{Ab}+\mathrm{An})$ is increased up to $\sim 37 \mathrm{wt}$. \% in the upper granites and normative orthoclase up to 35 wt. \% in the lower granites.

\subsection{How significant was the fractional crystallization?}

The results from the CS-1 drilling do not indicate any distinct separation of rock-forming minerals, not even between the textural variants. This observation is confirmed by planimetric analyses and normative compositions calculated from chemical analyses. The major-element composition was in principle preserved despite the significant later alteration. Also the textures resemble the primary magmatic ones, and the distribution of rock-forming minerals mirrors the feldspars-quartz equilibrium with the melt.

The lack of systematic vertical changes expected during settling of the rock-forming and accessory minerals is in line with the recent notion that fractional crystallization is not capable of explaining the enrichment in $\mathrm{Rb}, \mathrm{Cs}, \mathrm{Sn}, \mathrm{W}, \mathrm{U}, \mathrm{Li}, \mathrm{B}$ and $\mathrm{F}$ and depletion in $\mathrm{Sr}$ and Ba observed in most rare-metal granites (Dostal et al. 2015). Moreover, fractional crystallization model alone is not sufficient to explain the $\mathrm{Nb}-\mathrm{Ta}$ distribution in most peraluminous granites (Ballouard et al. 2016). In our case, this observation is supported by low $\mathrm{Nb} / \mathrm{Ta}$ ratios in the upper suite granites (c. 2-2.5), possibly providing an additional evidence of a later hydrothermal overprint on the chemical composition of the granites.

\subsection{Postmagmatic processes}

Rock-fluid interaction has been recognized as a dominant hydrothermal overprint of granites in the anorogenic columbite-bearing province of Northern Nigeria (Jacobson et al. 1958; Martin and Bowden 1981; Bowden et al. 1984). Evidence for the same processes has been found in a number of post-collisional rare-metal granite provinces of the former USSR, like Kazakhstan, Eastern Siberia and the Urals (Beus et al. 1962). This type of alterations has been identified also in the Cínovec granites (Štemprok 1965). The postmagmatic processes may have affected not only the original mineralogical composition formed by magmatic crystallization, but also some textural and structural features. Beus et al. (1962) called these granites "apogranites" stressing their association with normal granites, but having a different origin due to postmagmatic metasomatism. The main feature of these granites is their occurrence in the apical portions of cupolas or apophyses of the granite massifs controlled by 
the intensity of fracturing. Beus et al. (1962) and Beus and Zalashkova (1964) distinguished among apogranites: a) muscovite-albite apogranites with Be minerals, b) lithionite-amazonite albite apogranites with $\mathrm{Ta}$ and $\mathrm{Nb}$ minerals and c) riebeckite-albite apogranites with $\mathrm{Nb}, \mathrm{Zr}$ and REE minerals.

Central European apogranites do not carry amazonite in any of their varieties, are not enriched in Be and also do not contain alkaline amphiboles or pyroxenes. Cínovec granites can be linked with the group of apogranites containing Li-Fe micas and tantalite mineralization (Štemprok and Šulcek 1969; Rub et al. 1983, 1998).

The vertical sequence of alteration types in rare-metal granites was identified as early as in 1960's by Shcherba (1960) and Shcherba et al. (1964) in Kazakhstan greisen deposits and also referred to by Taylor (1979). The observations show that the granite cupolas are characterized by upward vertical sequences of postmagmatic alterations, from microclinization, through albitization to greisenization. Many apogranites are separated from one another, or from the country rock, by pegmatitic rims referred to as "stockscheider" in the Erzgebirge.

Similar sequence is documented by the drill core CS-1. The K-feldspar stringers and phenocrysts in lithian annite granites of the Cínovec/Zinnwald granite cupola resemble microclinization I in the Mesozoic provinces of Transbaikalia. There is also a massive albitization down to a depth of $730 \mathrm{~m}$ in the center of the cupola and K-feldspar enrichment below the ore zone (355-370 m) seems equivalent to microclinization II. Main greisen bodies are restricted to the top of the cupola and are accompanied by flat or steeply-dipping quartz veins.

The origin of both zinnwaldite and lithian annite in the upper and lower granite suites, respectively, was partly fracture-controlled. There is an especially common evidence of the fracture-controlled infilling of albiterich zinnwaldite granite by zinnwaldite in the Cínovec/ Zinnwald mine area. Microscopic evidence shows that the Li-Fe micas in the granite replace orthoclase along cleavage (Fig. 8e), presumably at subsolidus conditions. Such microtextures are commonly seen in granites below the mica transition zone. Numerous mica inhomogeneities include brown micas bleached to colorless or very light green varieties, which agree with the optical properties observed on zinnwaldite or "protolithionite" by Gottesmann and Tischendorf (1978). The fact that upper granites were originally lithian annite-bearing was well documented by Johan et al. (2012) by finding lithian annite crystals enclosed in a quartz crystal from a depth of $97 \mathrm{~m}$; the mica composition was verified by electronmicroprobe analysis.

The development of Li-Fe micas in albite granites of the Afu Complex in Nigeria (Bowden et al. 1984) carries many similarities with the Cínovec granites. It is characterized by changes from lepidolite-albite-quartzamazonite granites to dominant zinnwaldite types. Relict cores of more annitic and sideophyllitic micas can be overgrown by, or replaced by, zinnwaldite. The complex composition of Li-Fe micas plotted in the diagram devised by Rieder et al. (1970) shows transition from annite through zinnwaldite to "trilithionite".

Greisenization is a significant metasomatic process, which was related to fracturing in solid granite. In Cínovec it led to the origin of mainly quartz-zinnwaldite or quartz-topaz-zinnwaldite greisens bordering veins or forming massive lens-like bodies (Štemprok 1965; Seltmann et al. 1998).

A $15 \mathrm{~cm}$ long section across the contact between the zinnwaldite-albite granite and Teplice rhyolite was geochemically studied in the Zinnwald part of the deposit (Bühnau Stollen) by Tischendorf et al. (1988). The contact between the rock units is separated by a $6 \mathrm{~cm}$ thick stockscheider. Even though the studied zinnwaldite granite is strongly enriched in $\mathrm{Li}, \mathrm{Sn}, \mathrm{Rb}, \mathrm{Cs}, \mathrm{Ta}, \mathrm{Nb}$ and $\mathrm{Be}$, resembling the present data from the Cínovec part of the granite cupola, its geochemical effect on the countryrock Teplice rhyolite is very small (compare the values for the rhyolite/albite-rich granite: Li 116/1 $180 \mathrm{ppm}$, $\mathrm{Rb} 462 / 2,149$ ppm, Cs 16/49 ppm, Nb 23/172 ppm, Ta 0.9/39.9, Sn 17/90 ppm, Th 26/19 ppm, U 13/13 ppm).

\subsection{Petrological and geochemical classifications of granites}

The Cínovec/Zinnwald granites are alkali feldspar granites in IUGS classification (Le Bas and Streckeisen 1991), as any Ca-bearing plagioclase is absent and sodium feldspars are represented by albite with a very low An content. These Cínovec/Zinnwald granites are commonly termed "fractionated" and classified as A-type granites of the YIC (Seltmann et al. 1998; Breiter 2012). This idea is supported by the fact the upper suite granites are strongly enriched in HFSE and some LILE but are poor in trace elements compatible in mafic silicates $(\mathrm{Co}, \mathrm{Sc}$, $\mathrm{Cr}$ and $\mathrm{Ni}$ ) and feldspars (Ba, Sr, Eu). High $\mathrm{Fe} / \mathrm{Mg}$ ratios and increased $\mathrm{F}$ agree with the original definition of the A-type granites (see review by Bonin 2007).

Such compositions can be ascribed to mantle fluids as envisaged by the model of Martin (2006). A-type granitic magmas do arise by various mechanisms recently reviewed by Magna et al. (2010). These include remelting of a granulitic residue, anatexis of metaigneous crust, generation from mixed OIB and crustal sources, extensive fractional crystallization of a mantle-derived basaltic magma, melting of depleted mantle with imprint of subduction or anatexis of lower crust modified by mantle fluids. Thus several of these mechanisms require the participation of a mantle component to explain the specific 
chemical composition of the A-type granites which is also postulated as a condition for the origin of rare-metal mineralization in the Erzgebirge (Seifert 2009).

The lower suite granites texturally strongly resemble medium-grained porphyritic YIC granites of the Western Pluton of the KHEB (Štemprok 1965; Seltmann et al. 1998). The granites are peraluminous, mostly corundumnormative (CIPW), with average A/CNK of 1.12 for lithian annite granites and 1.15 for zinnwaldite granites. They correspond to plumasitic granites after Tauson (1977). The upper suite granites fulfil the criteria of apogranites (Beus et al. 1962) or Li-F granites and belong to their zinnwaldite-topaz-albite subtype (Syristo 2002).

The Cínovec/Zinnwald granites show the highest $\mathrm{SiO}_{2}$ contents (75-78 wt. \%) of all the YIC granites in the Eastern Krušné hory/Erzgebirge with the Li-Fe micas as the only dark mineral. Thus the differentiation index D.I. (wt. \%). in the granites ranges between 91.2 and 98.4 (Fig. 21). The Li-Fe nature of the micas makes the whole-rock $\mathrm{MgO}$ concentration extremely low, ranging from mean $0.14 \mathrm{wt}$ \% in zinnwaldite granite to 0.17 wt. $\%$ in lithian annite granite. The $\mathrm{FeO}$ concentration varies between $0.71 \mathrm{wt}$. \% in zinnwaldite granites and 0.54 wt. \% in lithian annite granites. The upper and lower suite granites are distinct in their trace-element compositions. The $\mathrm{Li}, \mathrm{Rb}, \mathrm{Cs}, \mathrm{F}, \mathrm{Sn}, \mathrm{Ta}$ and $\mathrm{Nb}$ concentrations are significantly elevated in the upper granite suite, while the $\mathrm{Zr}, \mathrm{Y}$, Th concentrations are lower than in the lower suite granites. The Cínovec granites are rich in $\mathrm{U}$ and $\mathrm{Th}$ and fulfil the criteria for high-heat production granites (Chlupáčová 2015). Although they could be potentially Ta-bearing, the increased concentrations of Ta are limited to the uppermost granite varieties (Cocherie et al. 1991; Rub et al. 1998) containing Ta minerals as subordinate accessories only. Thus, they differ from the Ta-bearing Mesozoic granites in Eastern Transbaikalia (Beus et al. 1962; Beus and Zalashkova 1964; Syritso 2002) by low

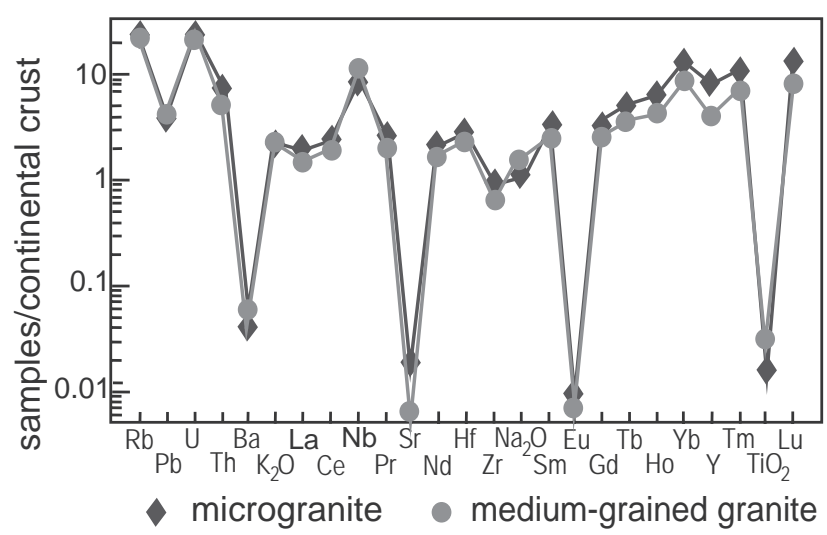

Fig. 22 Multi-element diagram for the granites at c. 724.6-8 m depth normalized by the average composition of the continental crust after Rudnick and Gao (2003). contents of of $\mathrm{Nb}$ and $\mathrm{Ta}$ minerals as well as by the lack of Be mineralization.

The multi-element plot (Fig. 22) shows no change for crustal abundance of $\mathrm{Zr}$, while $\mathrm{Rb}, \mathrm{Pb}, \mathrm{U}, \mathrm{Th}, \mathrm{K}_{2} \mathrm{O}, \mathrm{Nb}$, Hf, REE and $\mathrm{Y}$ are elevated above the crustal averages and $\mathrm{Ba}, \mathrm{Sr}, \mathrm{Eu}$ and $\mathrm{TiO}_{2}$ are significantly lower. A similar increase of $\mathrm{Rb}, \mathrm{Th}, \mathrm{Nb}$ and $\mathrm{Ta}$ was observed by Sala in Seltmann et al. (1998) in Zinnwald granites normalized by upper crustal abundances. The extreme chemical composition of upper granites (high albite, increased Li and F) is comparable with the chemical and mineralogical composition of ongonites, often used as a proof for the magmatic origin of albite rich Li-F granites (Kovalenko et al. 1970; Cuney et al. 1992).

Štemprok (1991) examined ongonites for possible deuteric effects and described phyllic alterations corresponding to a hydrothermal overprint, but failed to observe the effect of deuteric processes on the origin of albite and $\mathrm{Li}-\mathrm{Fe}$ micas. Recent petrographic and SEM-EDS work by Dostal et al. (2015) showed that ongonites underwent considerable reaction with deuteric fluids, and thus their primary magmatic signature has been modified, including the plagioclase and trioctahedral mica compositions. This emphasizes the similarity between the effects of processes observed in upper suite granites of the CS- 1 drill core and felsic dykes related to rare-metal mineralization observed in Mongolia.

\section{Models of magmatic-hydrothermal transition}

Most models of the granite origin presume that the earliest emplaced magma pulses formed a solid carapace, which was fractured by the later pulses and penetrated by fluids from the underlying hot magma (Burnham 1997). The concept of progressive evolution of a Sn-bearing granite melt was elaborated by Groves and McCarthy (1978), who postulated that the melts from the pluton's interior are forced to its top. For the development of the albite-rich granite cupolas, a more complex model has been developed (e.g., Syritso et al. 2001; Syritso 2002).

Johan et al. (2012) explained the enrichment in the apical part of the Cínovec/Zinnwald cupola by fluids rich in $\mathrm{Sn}, \mathrm{Nb}, \mathrm{Ta}$ and $\mathrm{W}$ released from the octahedral sites of lithian annite during its transformation to zinnwaldite, before the final crystallization of the granites. The concept does not explain sufficiently the hydrothermal enrichment of tungsten, an element unchanged in the micas of both suites (Fig. 10) even though Sn and W are jointly enriched in ore veins and greisens (Čabla and Tichý 1965; Seltmann et al. 1998).

The model by Breiter et al. (2015b) proposed that the mica-free granites zone and the K-feldspar enriched zone 

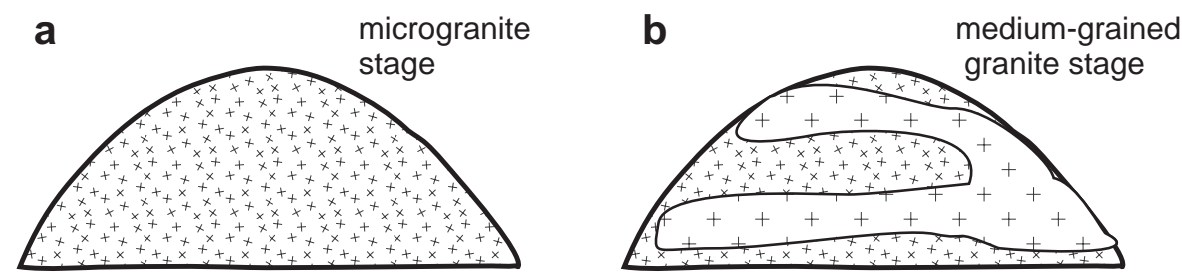

Fig. 23 Model for the origin of the Cínovec/Zinnwald granites and greisens revealed by the drill core CS-1 during four stages: a - microgranite intrusion; $\mathbf{b}$ - emplacement of mediumgrained granite; c - albitization and development of deuteric zinnwaldite at the top of the cupola; $\mathbf{d}$ - quartz veins origin and greisenization along fractured part of the cupola.

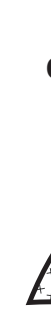

albitization and development of C zinnwaldite
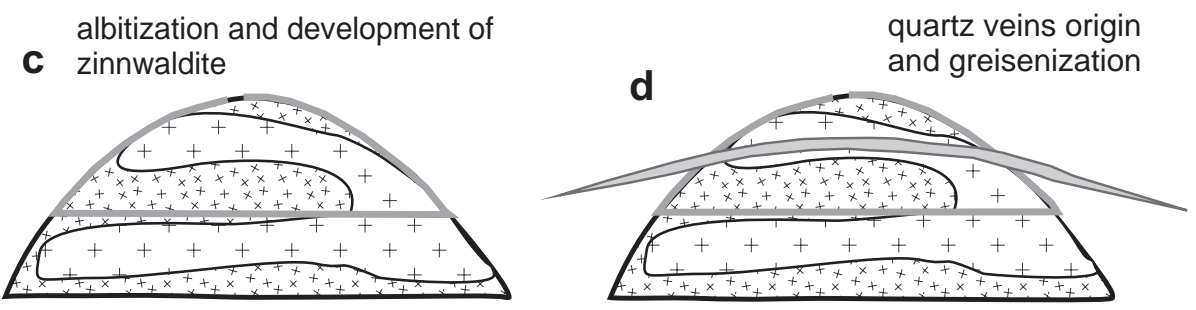

at a depth 359-368 $\mathrm{m}$ are restites formed after separation of fluids causing greisenization and silicification in the upper part. Late to postmagmatic unmixed fluids thus affected Cínovec cupola only to a depth of c. 370 $\mathrm{m}$ below the present surface. The explanation supposes a close temporal association between the solidification of the top of the granite cupola and the development of a fissure system. However, the gap between these two events remains unconstrained, and the flat veins are not dependent on the cupola structure but extend into the vicinal rhyolite.

Štemprok (1965) with Štemprok and Šulcek (1969) explained the association of Sn-W mineralization with the upper part of the granite cupola by the presence of the upper, slightly inclined upper granite contact that acted as a channel-way for ascending external solutions. No granitic variety encountered at Cínovec was identified as a source of the ore-bearing solutions. Tin-tungsten mineralization was a component of multiply ascending postmagmatic solutions, which transformed the upper part of the cupola and originated at depth. Epigenetic nature of this mineralization is indicated by association of increased Sn and W concentrations in the core samples in very $\mathrm{dm}$ scale sections, recorded in our study and with an epigenetically fractured granite at a depth of $1200 \mathrm{~m}$ (Štemprok 1964).

Taken together, the Cínovec/Zinnwald mineralization did not occur as consequence of fractional crystallization leading to residual fluids from any granite varieties found in the CS-1 drill core. The petrographic study could not identify any products of emplacement or crystallization from halogen-enriched melts, whose presence has been recorded by melt-inclusion studies of the Zinnwald granites (e.g. Webster et al. 2004). In this paper microgranitic variants are identified as the earliest granite formations emplaced during a primary magmatic stage of the KHEB two-phase granites. A model presented in Fig. 23 shows that the origin of microgranite was followed by the emplacement of medium-grained granite, identified as a new magmatic pulse replacing the microgranite along sub-horizontal structures. Hydrothermal albitization, possibly accompanied by transformation of lithian annite to zinnwaldite, occurred after the whole upper section was solidified and it influenced the known granite section down to a $730 \mathrm{~m}$ depth. Greisenization acted after fissuring of the granite occurred mainly to a depth of $c .200 \mathrm{~m}$. Effects of significant fracture-controlled alteration, such as phyllic mineral precipitation or fluorite and hematite growth, have been observed in the deepest known sections of the drill core and can be linked with numerous Late Variscan and post-Variscan hydrothermal events in the EVPC region.

\section{Conclusions}

The textural and geochemical studies of the Cínovec/ Zinnwald granite cupola revealed by the drill core CS-1 testifies a complex magmatic history of a multiply emplaced Late Variscan granite body in microgranitic and seriate medium-grained variants. The concentrations of $\mathrm{Li}, \mathrm{Na}, \mathrm{F}, \mathrm{Ta}, \mathrm{Rb}$ and $\mathrm{Cs}$ depend on the degree of hydrothermal overprint increasing from the bottom to the top of the cupola. The effect of textural variants on the changes in trace-element concentrations is insignificant, and suggests a joint hydrothermal overprint of microgranites and medium-grained granites in the upper granite suite. Greisenization enriched mainly the uppermost part of the cupola - subjected to fracturing - in Sn, W, Bi and As. The cupola served as a structural trap focusing the fluids of deep origin into upper crustal levels at the contact of the granite with the Teplice rhyolite. The concept thus contributes to solving the enigma how are the very viscous granitic magmas capable of concentrating large 
amounts of hydrothermal fluids in rapidly cooling, highlevel intrusive structures.

Acknowledgements. The first version of the paper was presented at the Workshop of the Grant Agency of the Czech Republic project P210/14/13600S held on Oct. 6, 2015 in Prague and organized by Karel Breiter. I am indebted to V. Vonásková for silicate analyses, O. Šebek for ICP-MS trace-element data, J. Bartošek for the radiometric analyses and M. Racek for the electron-microprobe analyses. I thank P. Bowden for substantial improving of the original version of the manuscript and numerous suggestions and comments. Critical readings of J.-L. Vigneresse and P. Bravo Silva with numerous proposals for improvements are gratefully acknowledged. I appreciate with thanks the help of handling editor V. Rapprich who carefully edited the text and improved figures and chief editor V. Janoušek who substantially contributed to the improvement of the final version of the manuscript by numerous critical comments and linguistic corrections. Thanks are due to Z. Procházka and O. Krýza for technical help with the manuscript preparation.

Electronic supplementary material. Concentrations of $\mathrm{Sn}$ and $\mathrm{Be}$ in the CS-1 drill core obtained by OES are available online at the Journal web site (http://dx.doi. org/10.3190/jgeosci.226).

\section{References}

ABUSHKEVICH VS, SYRITSo LF (2007) Isotopic-geochemical Model of the Li-F granites of the Khangilai Ore Knot in Eastern Transbaikalia. Nauka, Sankt-Petersburg, pp 1-147 (in Russian)

Ackerman L, Haluzová E, Creaser RA, Pašava J, Veselovský F, Breiter K, Erban V, Drábek M (in print) Temporal evolution of mineralization events in the Bohemian Massif inferred from Re-Os geochronology of molybdenite. Miner Depos, doi: 10.1007/s00126016-0685-5

Ballouard C, Poujol M, Boulvais P, Branquet Y, Tartèse $\mathrm{R}$, VIGNERESSE J-L (2016) Nb-Ta fractionation in peraluminous granites: a marker of the magmatic-hydrothermal transition. Geology 44: 231-234

Beus AA, Zalashrova NY (1964) Postmagmatic hightemperature metasomatic processes in granitic rocks. Int Geol Rev 6: 668-681

Beus AA, Severov EA, Sitnin AA (1962). Albitized and Greisenized Granites (Apogranites). Nauka, Moscow, pp 1-195 (in Russian)

Bonin B (2007) A-type granites and related rocks: evolution of a concept, problems and prospects. Lithos 97: 1-29

Bowden P, Kinnaird JA, Abaa SI, Ike EC, Turaki UM
(1984) Geology and mineralization of the Nigerian anorogenic ring complexes. Geol Jb B 56: 3-65

BREITER K (2012) Nearly contemporaneous evolution of the A-type and S-type fractionated granites in the Krušné hory/Erzgebirge Mts., Central Europe. Lithos 151: 105-121

BREITER K, ŠKODA R (2012) Vertical zonality of fractionated granite plutons reflected in zircon chemistry: the Cínovec A-type versus the Beauvoir S-type. Geol Carpath 63: 383-398

Breiter K, Ďurišová J, Korbelová, VañKová M, Vašinová M (2015a) Quartz, micas and ore minerals as expression of vertical zoning in the drill hole CS-1. In: BREITER K (ed) Workshop on the Vertical Zoning of Ore-bearing Granite Plutons in Light of Modern Analytical Methods, October 6, 2015, Abstracts. Prague, pp 7-9 (in Czech)

Breiter K, HRstKa T, RAMBousek P, KNÉsL I (2015b) Basis for a new model of ore-bearing process at Cínovec. In: BREITER $\mathrm{K}$ (ed) Workshop on the Vertical Zoning of Ore-bearing Granite Plutons in Light of Modern Analytical Methods, October 6, 2015, Abstracts. Prague, pp 15-18 (in Czech)

BuRnhAm CW (1997) Magmas and hydrothermal fluids. In: BARNES HL (ed) Geochemistry of Hydrothermal Ore Deposits. John Wiley and Sons, New York, pp 63-118

Chappell BW, Hine R (2006) The Cornubian Batholith: an example of magmatic fractionation on a crustal scale. Resour Geol 56: 203-244

Chappell BW, White AJR (1974) Two contrasting granite types. Pacific Geol 8: 173-174

ChlupéČOvÁ M (2015) Densities, porosity and radioactivity of the granites of the Cínovec-Krupka granite elevation. In: BREITER K (ed) Workshop on the Vertical Zoning of Ore-bearing Granite Plutons in Light of Modern Analytical Methods, October 6, 2015, Abstracts. Prague, pp 11-12 (in Czech)

Chlupéčová M, ŠTeMprok M (1965) Distribution of densities of granitic rocks in the Cínovec Massif. Věst ÚUUG 40: 1-17 (in Czech)

Cobbing EJ, Pitfield PEJ, Darbyshire DPF, Mallick DiJ (1992) The Granites of the South-East Asian Tin Belt. British Geological Survey Overseas Memoirs 10: pp 1-369

Cocherie A, Johan V, Rossi P, Štemprok M (1991) Trace element variation and tetrad effect studied in a Variscan lithium albite granite. Case of the Cínovec granite (Czechoslovakia). In: PAgel M, Leroy JL (eds) Source, Transport and Deposition of Metals. Balkema, Rotterdam, pp 745-749

Cuney M, Barbey P (2014) Uranium, rare metals, and granulite-facies metamorphism. Geosci Frontiers 5: 729-745

Cuney M, Marignac C, Weisbrod A (1992) The Beauvoir topaz-lepidolite albite granites (Massif Central, France): the disseminated magmatic $\mathrm{Sn}-\mathrm{Li}-\mathrm{Ta}-\mathrm{Nb}-\mathrm{Be}$ mineralization. Econ Geol 87: 1766-1794 
ČABla V, TichÝ K (1965) New results of geological exploration at Cínovec. Sbor geol Ved, Lož Geol Mineral 5: 107-129 (in Czech)

Černý P, Blevin P L, Cuney M, London D (2005) Granite related ore deposits. Econ Geol 10 $0^{\text {th }}$ Ann Vol: 337-370

Dolesš D, ŠTEMProk M (2001) Magmatic and hydrothermal evolution of Li-F granites, Cínovec and Krásno intrusions, Krušne hory Batholith, Czech Republic. Bull Czech Geol Surv 76: 77-99

Dolejš D, Bendl J, ŠTemprok M (2016) Rb-Sr isotopic composition of granites in the Western Krušné hory/ Erzgebirge Pluton, Central Europe: record of variation in source lithology, mafic magma input and postmagmatic hydrothermal overprint. Miner Petrol 110: 601-622

Dostal J, Kontak DJ, Gerel O, Shellnutt JG, Fayek M (2015). Cretaceous ongonites (topaz-bearing albite-rich microleucogranites) from Ongon Khairkhan, Central Mongolia: products of extreme magmatic fractionation and pervasive metasomatic fluid-rock interaction. Lithos 236-237: 173-189

Fiala F (1968) Granitoids of the Slavkovský (Císařský) les. Sbor Geol Věd, Geol 14: 93-160

GerstenBERger H (1989) Autometasomatic Rb enrichments in highly evolved granites causing lowered $\mathrm{Rb}-\mathrm{Sr}$ isochron intercepts. Earth Planet Sci Lett 93: 65-75

Gottesmann B, Tischendorf G (1978) Klassifikation, Chemismus und Optik trioktaedrischer Glimmer. Z geol Wiss 6: 681-708

Groves DI, Mc CARThy TS (1978) Fractional crystallization and the origin of tin deposits in granitoids. Miner Depos 13: 11-26

Hoefs J (1997) Stable Isotope Geochemistry, $4^{\text {th }}$ edition. Springer Verlag, Berlin, pp 1-201

HOLLOCHER K (2016) NORM4. macro-enabled version for multiple samples. Accessed on January 10, 2017, at http://minerva.union.edu/hollochk/c_petrology/ other files/norm4.xlsm

Hösel G, Tischendorf G, Wasternack J, Breiter K, Kuschka E, Pälchen W, Rank G, Štemprok M (1997) Erläuterungen zur Karte Mineralische Rohstoffe Erzgebirge-Vogtland/Krušné hory 1:100 000, Karte 2, Metalle, Fluorit/Baryt - Verbreitung und Auswirkung auf die Umwelt. Landesamt für Umwelt und Geologie, Bergbau in Sachsen, Freiberg, pp 1-144

JaCoBSon RRE, MACLEOD WN, BlaCk R (1958) Ring complexes in the Younger granite province of Northern Nigeria. Geological Society, London, Memoirs 1: pp 1-71

Johan Z, Johan V (2005) Accessory minerals of the Cínovec (Zinnwald) granite cupola, Czech Republic: indicators of petrogenetic evolution. Mineral Petrol 83: 113-150

Johan Z, Strnad L, Johan V (2012) Evaluation of the Cínovec/Zinnwald granite cupola, Czech Republic; composition of feldspars and micas, a clue to the origin of W, Sn mineralization. Canad Mineral 50: 1131-1148
Kovalenko VI, Kuzmin MI, Ceden C, Vladykin NV (1970) Lithium-fluorine quartz keratophyre (ongonite): a new variety of subvolcanic magmatic dykes. Ezhegodnik 1969, Siberian Institute of Geochemistry, Irkutsk, pp 85-99 (in Russian)

Lange H, Tischendorf G, PÄlchen W, Klemm I, Ossenkopf E (1972) Fortschritte der Metallogenie im Erzgebirge. B. Zur Petrographie und Geochemie der Granite des Erzgebirges. Geologie 21: 491-521

Le Bas MJ, Streckeisen A (1991) The IUGS systematics of igneous rocks. J Geol Soc, London 148: 825-833

LeHMANN B (1982) Metallogeny of tin: magmatic differentiation versus geochemical heritage. Econ Geol 17: 50-59

Magna T, Janoušek V, Kohút M, Oberli $\mathrm{F}$, Wiechert U (2010) Fingerprinting sources of orogenic plutonic rocks from Variscan belt with lithium isotopes and possible link to subduction-related origin of some A-type granites. Chem Geol 274: 94- 107

MARTIN RF (2006) A-type granites of crustal origin ultimately results from open-system fenitization type reactions in an extensional environment. Lithos 91: 125-136

Martin RF, Bowden P (1981) Peraluminous granites produced by rock-fluid interaction in the Rirwain anorogenic ring complex, Nigeria, Mineralogical evidence. Canad Mineral 19: 65-82

MLČOCH B, SKÁCELOVÁ Z (2010) Geometry of the AltenbergTeplice Caldera revealed by the bore hole and seismic data in the Czech part. J Geosci 55: 217-229

Monecke T, Dulski P, Kempe U (2007) Origin of convex tetrads in rare earth element patterns of hydrothermally altered siliceous igneous rocks from the Zinnwald Sn-W deposit, Germany. Geochim Cosmochim Acta 71: 335-353

Oelsner O (1952) Die pegmatitisch-pneumatolytischen Lagerstätten des Erzgebirges mit Ausnahme der Kontaktlagerstätten. Freiberg Forsch H C 9: 1-80

Pirajno F (2009) Hydrothermal Processes and Mineral Systems. Springer and Geological Survey of Western Australia, Perth, pp 1-1250

Pollard P J, TAylor RG, Cuff C (1988) Genetic modeling of greisens-style tin systems. In: Hutchison CS (ed) Geology of Tin Deposits in Asia and the Pacific. Springer, Berlin, pp 59-72

RAMBousek P, KNÉsL I (2015) Preliminary statistical evaluation of analytical data from the drill hole CS-1 and its implication for metallogenic development of $\mathrm{Sn}-\mathrm{W}, \mathrm{Li}$ (Nb-Ta) mineralization. In: BREITER K (ed) Workshop on the Vertical Zoning of Ore-bearing Granite Plutons in Light of Modern Analytical Methods, October 6, 2015, Abstracts. Prague, pp 4 (in Czech)

Rieder M, Huka M, KuČerová D, Minařík L, Obermajer J, PovondRa P (1970) Chemical composition and physical of lithium-iron micas from the Krušnè hory Mts. (Erzgebirge), part A: chemical composition. Contrib Mineral Petrol 27: 131-158 
Rieder M, CaVazzini C, D'yakonov YS, Frank-KamenitskiI VA, Gottardi G, Guggenheim S, Koval PV, Müller G, Neiva AMR, Radoslovich EW, Robert J-L, Sassi FP, TAKeda H, Weiss Z, Wones DR (1998) Nomenclature of the micas. Canad Mineral 36: 905-912

Romer RL, Kroner U (2015) Phanerozoic tin and tungsten mineralization - tectonic controls on the distribution of enriched protoliths and heat sources for crustal melting. Gondwana Res 31: 60-95

Romer RL, Thomas R, Stein HJ, Rhede D (2007) Dating multiply overprinted Sn-mineralized granites - examples from the Erzgebirge, Germany. Miner Depos 42: 337-359

Romer RL, Förster H-J, ŠTemprok M (2010a) Age constrains for the late-Variscan magmatism in the AltenbergTeplice Caldera (Eastern Erzgebirge/Krušné hory). Neu Jb Mineral, Abh 187: 289-305

Romer RL, Schneider JC, Linnemann U (2010b) PostVariscan deformation and hydrothermal mineralization in Saxo-Thuringia and beyond: a geochronological review. In: Linnemann U, Romer RL (eds), Pre-Mesozoic Geology of Saxo-Thuringia: From Cadomian Active Margin to the Variscan Orogen. Schweitzerbartsche Verlag, Stuttgart, pp 347-360

Rub MG, Pavlov VA, Rub AK, ŠTemprok M, DrÁbKová E, DRÁBEK M (1983) Vertical zoning of the Cínovec granite massif of lithium-fluorine granites (ČSSR). In: Bogatikov OA, Borsuk AM (eds) Correlation of Magmatic Rocks of Czechoslovakia with Some Districts of the USSR. Nauka, Moscow, pp 108-137 (in Russian)

Rub AK, ŠTEMProK M, Rub MG (1997) Tantalum mineralization in rare-metal granites of the Cínovec Massif (Czechia), Dokl Akad Nauk, Geologiya 352: 795-798 (in Russian)

Rub AK, ŠTEMProk M, Rub MG (1998) Tantalum mineralization in the apical part of the Cínovec (Zinnwald) granite stock. Mineral Petrol 63: 199-222

Rudnick RL, GaO S (2003) Composition of the continental crust. In: RuDNICK RJ (ed) The Crust. Treatise on Geochemistry, Vol. 3. Elsevier-Pergamon, Oxford, pp 1-64

RYKL D, ŠTEMPROK M (1992) Hydrothermal reactions of $\mathrm{NaCl}$ and $\mathrm{KCl}$ brines with the Cínovec granite at $400^{\circ} \mathrm{C}$ and $50 \mathrm{MPa}$ : an experimental study. Bull Czech Geol Surv 67: 155-168

SEIFERT T (2009) Metallogeny and Petrogenesis of Lamprophyres in the Mid-European Variscides: Post-collisional Magmatism and Its Relationship to Late-Variscan Ore Forming Processes in the Erzgebirge (Bohemian Massif). IOS Press, Amsterdam, pp 1-304

Seifert T, Pavlova GG (2016) New ${ }^{40} \mathrm{Ar} /{ }^{39} \mathrm{Ar}$ ages of Sn- and W-polymetallic mineralization in the Erzgebirge/Krušné hory (DE, CZ). In: Goldschmidt Conference Yokohama, June $26^{\text {th }}-$ July $1^{\text {st }}, 2016$, Abstracts, pp 2792
Seifert T, Atanasova P, Gutzmer J, Pfänder J (2011) Mineralogy, geochemistry and age of greisen mineralization in the $\mathrm{Li}-\mathrm{Rb}-\mathrm{Cs}-\mathrm{Sn}-\mathrm{W}$ deposit Zinnwald, Erzgebirge, Germany. Mineral Mag 75 (Suppl): 1833

Seltmann R, ŚTemprok M (1994) Textural evidence for the existence of two-phase granites in the Younger Intrusive Complex granites of the Krušné hory/Erzgebirge province. J Czech Geol Soc 39: 103-104

Seltmann R, Förster H-J, Gottesmann B, Sala M, Wolf D, ŠTEMPRoK M (1998) The Zinnwald greisen deposit related to post-collisional A-type silicic magmatism in the Variscan Eastern Krušnè hory/Erzgebirge. In: BREITER K (ed) Genetic Significance of Phosphorus in Fractionated Granites. Excursion guide. Czech Geological Survey, Prague, pp 33-49

SHCHERBA GN (1960) Formation of rare-metal deposits of Central Kazakhstan. Izdatelstvo Akademii Nauk Kazakhskoi SSR, Alma Ata, pp 1-260 (in Russian)

Shcherba GN, Gukova VD, Kudryashov AV, Senchilo NP (1964) Greisens, vein quartz and potash feldspars of molybdenum-tungsten deposits. Izdatelstvo Akadademii Nauk Kazakhskoi SSR, Alma-Ata, pp 1-307 (in Russian)

Steiger RH, JäGER E (1977) Subcommission on geochronology: convention on the use of decay constants in geo- and cosmochronology. Earth Planet Sci Lett 36: 359-362

Sun SS, McDonough WF (1989) Chemical and isotopic systematics of oceanic basalts: implications for mantle composition and processes. In: SAUNDERS AD, NorRY MJ (eds) Magmatism in the Ocean Basins. Geological Society of London Special Publications 42: 313-345

SyRITSO LF (2002) Mesozoic Granitoids of Eastern Transbaikalia and Problems of Rare Metal Mineralization. Izdatelstvo St.-Petersburgskogo Universiteta, St. Petersburg, pp 1-357 (in Russian)

Syritso LF, Tabuns EV, Volkova EV, Badanina EV, Vysotskil YuA (2001) Model for the genesis of Li-F granites in the Orlovka Massif, Eastern Transbaikalia. Petrology 9: 268-289

ŠKVOR V (1974) Geology of the Czech part of the Krušné hory and Smrčiny. Knihovna Ústředního ústavu geologického 48: pp 1-119 (in Czech)

ŠTEMPROK M (1964) Traces of sulphide and greisen mineralization in the deep parts of the Cínovec (Zinnwald) granite massif. Věst ÚÚG 39: 211-213

ŠTEMPROK M (1965) Petrography and the vertical extent of mineralization in the Cínovec granite cupola. Sbor Geol Věd, lož Geol Mineral 5: 7-106 (in Czech)

ŠTEMPROK M (1989) Rare-earth elements in the rocks of the Cínovec granite cupola (Czechoslovakia). Bull Czech Geol Survey 64: 1-15

ŠTEMProK M (1991) Ongonite from Ongon Khairkhan, Mongolia. Mineral Petrol 43: 255-273 
ŠTEMPRoK M, Seifert T (2011) An overview of the association between lamprophyric intrusions and rare-metal mineralization. Mineralogia 42: 121-162

Štemprok M, Š́lcek Z (1969) Geochemical profile through an ore-bearing lithium granite. Econ Geol 64: 392-404

ŠTEMPRoK M, Novík JK, DAVID J (1994) The association between granites and tin-tungsten mineralization in the eastern Krušné hory (Erzgebirge), Czech Republic. In: von Geohlen K, Klemm DD (ed) Mineral Deposits of the Erzgebirge/Krušné hory (Germany/Czech Republic). Monograph Series on Mineral Deposits 31, Gebrueder Borntraeger, Berlin-Stuttgart, pp 97-129

ŠTemproK M, Holub FV, NovÁK JK (2003) Multiple magmatic pulses of the Eastern Volcano-Plutonic Complex, Krušné hory/Erzgebirge Batholith and their phosphorus contents. Bull Geosci 78: 277-296

Štemprok M, Dolejš D, Müller A, Seltmann R (2008) Textural evidence of magma decompression, devolatilization and disequilibrium quenching: an example from the Western Krušné hory/Erzgebirge granite pluton. Contrib Mineral Petrol 155: 93-109

Štemprok M, Dolejš D, Holub FV (2014) Late Variscan calc-alkaline lamprophyres in the Krupka ore district, Eastern Krušné hory/Erzgebirge: their relationship to Sn-W mineralization. J Geosci 59: 41-68

Tauson LV (1977) Geochemical Types and Potential Orebearing Capacity of Granitoids. Nauka, Moscow, pp $1-279$ (in Russian)

TAYlor RG (1979) Geology of Tin Deposits. Elsevier, Amsterdam, pp 1-543
TAYLOR RP, FALLICK AE (1997) The evolution of fluorine-rich felsic magmas: source dichotomy, magmatic convergence and the origin of topaz granites. Terra Nova 9: 105-108

TindLE AG (2001) Biotite etc. formula unit calculations. Accessed January 4, 2017 at http://www.open.ac.uk/ earth-research/tindle/AGTWebData/Mica-bio.xls

Tindle AG, Webi PC (1990) Estimation of lithium contents in trioctahedral micas using microprobe data: application to micas from granitic rocks. Eur J Mineral 2: 595-610

Tischendorf G, Gottesmann B, Förster H-J, Trumbull RB (1997) On Li-bearing micas: estimating Li from electron microprobe analyses and an improved diagram for graphical presentation. Mineral Mag 61: 809-834

Tischendorf G, Just G, GotTesmann B (1988) Distribution of elements at a contact albite granite/rhyolite, Zinnwald, Erzgebirge (G.D.R.). Chem Erde 48: 155-162

Walther D, Breitkreuz C, Rapprich V, Kochergina YV, Chlupáčová M, Lapp M, Stanek K, Magna T (2016) The Late Carboniferous Schönfeld-Altenberg Depression on the NW margin of the Bohemian Massif(Germany/Czech Republic): volcanosedimentary and magmatic evolution. J Geosci 61: 371-393

Webster J, Thomas R, Förster H-J, Seltmann R, Tappen C (2004) Geochemical evolution of halogen-enriched granite magmas and mineralizing fluids of the Zinnwald tin-tungsten mining district, Erzgebirge, Germany. Mineral Depos 39: 452-472

WeIss D (1983) Methods of Chemical Analysis of Mineral Resources, vol. 2-3. Czech Geological Survey, Prague, pp 157-302 (in Czech)

Zhao Z, Masuda A, Shabani MB (1993) REE tetrad effects in rare-metal granites. Chinese J Geochem 12: 206-219 